\title{
Revving up natural killer cells and cytokine-induced killer cells against hematological malignancies
}

OPEN ACCESS

Edited by:

Raquel Tarazona,

University of Extremadura, Spain

Reviewed by:

Roberto Biassoni,

Istituto Giannina Gaslini, Italy Björn Önfelt,

Karolinska Institutet, Sweden

${ }^{*}$ Correspondence:

Gianfranco Pittari,

Department of Medical Oncology, National Center for Cancer Care and

Research, Hamad Medical

Corporation, P.O. Box 3050,

Doha, Qatar

gpittari@hamad.qa;

Sergio Rutella,

Clinical Research Center, Division of Translational Medicine, Sidra Medical and Research Center,

P. O. Box 26999, Doha, Qatar srutella@sidra.org

Specialty section:

This article was submitted to NK Cell Biology, a section of the journal

Frontiers in Immunology

Received: 27 March 2015

Accepted: 29 April 2015

Published: 13 May 2015

Citation:

Pittari G, Filippini P, Gentilcore G, Grivel J-C and Rutella S (2015) Revving up natural killer cells and cytokine-induced killer cells against hematological malignancies.

Front. Immunol. 6:230.

doi: 10.3389/fimmu.2015.00230

\author{
Gianfranco Pittari $^{1 *}$, Perla Filippini ${ }^{2}$, Giusy Gentilcore ${ }^{2}$, Jean-Charles Grivel ${ }^{2}$ and \\ Sergio Rutella ${ }^{3 *}$
}

${ }^{1}$ Department of Medical Oncology, National Center for Cancer Care and Research, Hamad Medical Corporation, Doha, Qatar,
${ }^{2}$ Deep Immunophenotyping Core, Division of Translational Medicine, Sidra Medical and Research Center, Doha, Qatar, ${ }^{3}$ Clinical
Research Center, Division of Translational Medicine, Sidra Medical and Research Center, Doha, Qatar

Natural killer (NK) cells belong to innate immunity and exhibit cytolytic activity against infectious pathogens and tumor cells. NK-cell function is finely tuned by receptors that transduce inhibitory or activating signals, such as killer immunoglobulin-like receptors, NK Group 2 member D (NKG2D), NKG2A/CD94, NKp46, and others, and recognize both foreign and self-antigens expressed by NK-susceptible targets. Recent insights into NK-cell developmental intermediates have translated into a more accurate definition of culture conditions for the in vitro generation and propagation of human NK cells. In this respect, interleukin (IL)-15 and IL-21 are instrumental in driving NK-cell differentiation and maturation, and hold great promise for the design of optimal NK-cell culture protocols. Cytokine-induced killer (CIK) cells possess phenotypic and functional hallmarks of both T cells and NK cells. Similar to T cells, they express CD3 and are expandable in culture, while not requiring functional priming for in vivo activity, like NK cells. CIK cells may offer some advantages over other cell therapy products, including ease of in vitro propagation and no need for exogenous administration of IL-2 for in vivo priming. NK cells and CIK cells can be expanded using a variety of clinical-grade approaches, before their infusion into patients with cancer. Herein, we discuss GMP-compliant strategies to isolate and expand human NK and CIK cells for immunotherapy purposes, focusing on clinical trials of adoptive transfer to patients with hematological malignancies.

Keywords: natural killer cell, cytokine-induced killer cell, interleukin-2, interleukin-15, good manufacturing practice, leukemia, immunotherapy

\section{Biological Features of NK, LAK, and CIK Cells}

Natural killer (NK) cells comprise 5-25\% of peripheral blood (PB) lymphocytes and were initially recognized for their ability to kill cancer cells without prior sensitization. The reader is referred to previously published papers for a thorough review of NK development and function (1-3). Briefly, NK cells originate from bone marrow (BM) $\mathrm{CD} 34^{+}$hematopoietic stem cells and can also be differentiated in vitro from highly immature CD34- umbilical cord blood (UCB) cells (4). NK cells acquire function (killing or cytokine production) after encountering and recognizing self-human leukocyte antigen (HLA) molecules during a process termed "licensing" or NK-cell education. However, $10-20 \%$ of NK cells remain unlicensed, as they lack receptors for self-major histocompatibility complex (MHC) and are functionally hyporesponsive. Importantly, unlicensed 
NK cells can become alloreactive upon encounter with cytokines in a recipient environment, e.g., after adoptive transfer into hematopoietic stem cell transplantation (HSCT) recipients.

The function of NK cells is governed by a set of germlineencoded activating or inhibitory receptors referred to as killer immunoglobulin-like receptors (KIRs). The extracellular domain determines which HLA class I molecule NK cells recognize, whereas the intracytoplasmic domain transmits either an activating or an inhibitory signal. KIRs are monomeric receptors with either 2 (KIR2D) or 3 (KIR3D) immunoglobulin-like domains, and are further subdivided into those with long (L) cytoplasmic tails (KIR2DL and KIR3DL) and short (S) cytoplasmic tails (KIR2DS and KIR3DS) (5-7). Long-tail KIRs generate an inhibitory signal through the recruitment of the SH2-domaincontaining tyrosine phosphatase 1 protein (SHP1) (8-11). Shorttail KIRs possess truncated portions that transduce activating signals via tyrosine phosphorylation of DAP12 and other proteins (12-14).

Natural killer cells also express other activating receptors that recognize "stress ligands" on virally infected or malignant cells. For instance, NKG2D, a C-type lectin receptor that belongs to the NK group 2 (NKG2) of receptors as member D (15), is constitutively expressed on $\mathrm{NK}$ cells and recognizes $\mathrm{MHC}$ class I chain-related genes A and B (MICA and MICB) (16), as well as unique long 16 (UL16) binding protein family members (ULBPs) (17). Other activating molecules include natural cytotoxicity receptors (NCRs) NKp30, NKp44, and NKp46 (18, 19). It has been shown that killing of tumors of non-epithelial origin, including leukemia cell lines, involves synergism between NCRs and NKG2D (20). Activating KIRs, such as KIR2DS1, are likely involved in the anti-leukemia effect of NK cells $(21,22)$. In 2002, investigators from Perugia demonstrated superior diseasefree survival (DFS) in patients with acute myeloid leukemia (AML) receiving BM grafts from HLA-haploidentical donors who expressed KIR binding to MHC class I molecules absent in the host (i.e., KIR-ligand mismatch in the GVH direction) $(23,24)$. The most notable inhibitory receptors recognize HLA class I proteins (including groups of HLA-A, HLA-B, and HLAC) and differ in both their transmembrane and intracytoplasmic domains (25-29).

Human leukocyte antigen-C is the predominant class I isotype involved in the inhibitory and activating regulation of human NK cells $(1,22)$. Individuals may have up to $15 \mathrm{KIR}$ genes that reside in a single complex on chromosome 19p13.4. KIR genes can be divided into A or B haplotypes. The A haplotype consists of five inhibitory KIRs and a single activating KIR, KIR2DS4. By contrast, the B haplotype contains both inhibitory and several activating KIRs that are further subdivided into two separate regions, centromeric and telomeric. In the "missing self" model (30), donor NK cells express inhibitory KIRs for which HLA class I molecules are missing in the recipient. Donors with KIR B vs. KIR A haplotypes improve the clinical outcome for patients with AML by reducing the incidence of leukemia relapse and prolonging DFS (31). The centromeric KIR B genes were dominant over the telomeric ones, and included the genes encoding inhibitory KIRs that are specific for the $\mathrm{C} 1$ and $\mathrm{C} 2$ epitopes of HLA-C. When the authors examined a cohort of 1,532 T-cell-replete HSCT, relapse protection associated with donor KIR B was enhanced in recipients with one or two C1-bearing HLA-C allotypes compared with homozygous recipients. This implies that a deeper understanding of the interaction between donor KIRs and recipient HLA class I will allow the selection of the "best donor" to improve outcomes of unrelated HSCT and adoptive NK infusion for AML. Intriguingly, KIR B haplotype donors were recently shown to confer a reduced risk for relapse after haploidentical HSCT in children with ALL (32), an effect that is not seen in adult ALL (33). In allogeneic HSCT, particularly from HLA-mismatched donors, NK cells reportedly influence clinical outcome by exerting anti-tumor effects without inducing graft-versus-host disease (GVHD) (34). However, NK cells reconstituting after allogeneic HSCT may be dysfunctional, likely as a result of low IL-2 levels (35). Some groups are attempting to improve NK-cell reconstitution following HSCT by depleting the graft of $\alpha \beta^{+} \mathrm{T}$ cells and $\mathrm{CD} 19^{+} \mathrm{B}$ cells, but leaving NK progenitors untouched (36). Using this approach, very high numbers of haploidentical NK cells and NK-like $\left(\mathrm{CD}^{+} 6^{+}\right) \mathrm{T}$ cells can be infused into patients with malignant disorders (37).

Another family of human NK receptors is composed of a common subunit (CD94), covalently linked to a distinct chain encoded by a C-type lectin NKG2 family gene. Among the Ctype lectin NK receptors, CD94/NKG2A is inhibitory, whereas other heterodimers are activating receptors. CD94/NKG2A binds the non-classical class I molecule HLA-E (38). The binding of a unique peptide/HLA-E complex to the activating CD94/NKG2C receptor is of higher affinity than the binding to the inhibitory CD94/NKG2A ensuring the predominance of inhibitory signals when the same NK cells express both activating and inhibitory receptors recognizing HLA molecules (39).

In 1980, Rosenberg and co-workers demonstrated that incubation of heterogeneous lymphocyte populations with high-dose (800-1,000 U/ml) interleukin-2 (IL-2) generates lymphokineactivated killer (LAK) cells with prompt in vitro cytotoxicity to syngeneic and autologous fresh tumors (40-42). NK cells were identified as precursors of LAK cells, and LAK activity was found to be mainly, albeit not uniquely, mediated by activated $\mathrm{NK}$ cells $(43,44)$. LAK cells comprise $\mathrm{CD}^{-}{ }^{-} \mathrm{CD} 56^{+} \mathrm{NK}$ cells, MHCunrestricted cytotoxic $\mathrm{CD} 3{ }^{+} \mathrm{CD}_{5} 6^{+} \mathrm{T}$ cells, and $\mathrm{CD} 3{ }^{+} \mathrm{CD} 56^{-} \mathrm{T}$ cells. However, LAK cells had limited expansion in vitro and low cytolytic activity in vivo. Furthermore, LAK therapy required high doses of IL-2 in vivo and was associated with relevant toxicity. Modifications in culture conditions, i.e., provision of agonistic $\alpha \mathrm{CD} 3$ (OKT3) monoclonal antibodies (mAbs), IL-2 and interferon (IFN)- $\gamma$, translated into $>1,000$-fold expansion of peripheral blood mononuclear cells (PBMCs) with potent cytokine-induced killer (CIK) activity. CIK cells share phenotypic and functional properties of both T cells and NK cells, as they co-express CD3 and CD56, and are rapidly expandable in culture like T cells, while not necessitating functional priming for in vivo activity, analogous to NK cells. Interestingly, CIK cells do not recognize target cells through the T-cell receptor (TCR) and do not require the presence of MHC molecules on target cells, as suggested by the observation that cytotoxicity is not affected by antibody masking of the TCR or MHC class I or class II molecules. CIK cells also express activating NK receptors, including NKG2D, DNAX accessory molecule-1 (DNAM), and NKp30 $(45,46)$. 
Evidence for an in vivo activity of CIK cells derives from studies in a murine severe combined immune deficiency (SCID)/human lymphoma model, where co-administration of CIK cells with B-lymphoma cells had favorable effects on mice survival, with a 1.5-2.0-log cell kill and only marginal toxicity against normal hematopoietic precursors (47). CIK cells reportedly protect against syngeneic and allogeneic tumors also in other experimental models, including nude mice xenografted with human cervical carcinoma cells (48-50). CIK cells are detected in the lungs $30 \mathrm{~min}$ after injection, followed by distribution to other sites, such as the liver and spleen and, by $72 \mathrm{~h}$, the tumor site, where CIK cells may remain for more than 9 days (51).

\section{Current NK-Cell Manufacturing Practices}

A direct comparison of $\mathrm{NK}$ manufacturing techniques is hampered by differences in starting materials, technologies, and manipulation strategies (52, 53). Classically, GMP-compliant NK-cell products have been generated from PBMCs collected by apheresis (Table 1). It has been shown that NK cells obtained from granulocyte colony-stimulating factor (G-CSF)-mobilized leukapheresis products have reduced functional capacity (54). Conceivably, non-mobilized blood may be preferable over G-CSF mobilized blood as a source of NK cells for immunotherapy trials. A variety of cellular media have been used to culture NK cells, including X-VIVO serum-free medium, AIM V, or stem cell growth medium (SCGM), typically supplemented with 5-10\% human $\mathrm{AB}$ serum to enhance NK function. Because the limited number of NK cells in leukapheresis products restricts clinical applicability, in vitro methods to expand NK cells are intensely being developed. In this respect, IL-15 promotes NK-cell proliferation and survival, and has been variably used in GMP-grade laboratory protocols, as further detailed below. Alternative methods of expansion rely on human feeder cells, including artificial antigen presenting cells (APCs) that are modified with costimulatory molecules, such as CD137 ligand, and membrane-bound (mb) IL-15 or IL-21. However, expanded NK cells undergo exhaustion, as shown by telomere shortening and replicative senescence.

In 2001, Carlens and co-workers described a cytokine-based technique for in vitro enrichment of human NK cells from bulk PBMCs of healthy individuals (79). PBMCs were incubated in SCGM containing 5\% human serum and varying concentrations of IL-2. In addition, stimulation with OKT3 at $10 \mathrm{ng} / \mathrm{ml}$ was provided during the first 5 days of the culture. Supplementation with $500 \mathrm{U} / \mathrm{ml}$ IL-2 yielded a median 193-fold cell expansion in 21 days. Fifty-five percent of the expanded cells had a CD3 ${ }^{-} \mathrm{CD}_{5}{ }^{+}$phenotype, and prolongation of the culture beyond 3 weeks did not allow further NK-cell enrichment. Moreover, expansion of the NK-cell compartment was comparable in cultures containing IL2 concentrations ranging from 100 to $1,000 \mathrm{U} / \mathrm{ml}$. Expanded cells could efficiently kill the NK-susceptible K562 line. This protocol was subsequently applied to PBMCs from patients with multiple myeloma (MM), an incurable plasma cell malignancy with a unique ability to subvert anti-tumor immune responses (80). Following an initial non-proliferative phase of 5 days, patientderived NK cells expanded 1,625-fold on average after 20 days of culture (71). NK cells from MM patients displayed increased expression of multiple activating receptors, including 2B4, NKp46,
NKp44, NKp30, NKG2D, and DNAM-1, and were efficiently cytotoxic to K562 cells and primary autologous MM cells, but not to autologous $\mathrm{CD}^{+}{ }^{+}$cells (71). Mobilized PBMCs from patients with MM have also been used to expand NK cells (81). After a 7-day culture with serum-free AIM V media, IL-2 and OKT3, polyclonal populations of cytotoxic lymphocytes were detected, including $\mathrm{CD}^{+} \mathrm{T}$ cells, $\mathrm{CD} 8^{+} \mathrm{T}$ cells, $\mathrm{CD} 8^{+} \mathrm{CD} 56^{+} \mathrm{T}$ cells, and $\mathrm{CD} 6^{+} \mathrm{NK}$ cells. Culture bags provided a two- to threefold expansion of immune effectors that retained their cytotoxicity after cryopreservation and thawing.

Notably, ex vivo expansion of NK cells from PBMCs incubated with IL-2 was also pursued under GMP-compliant conditions. Using an automated bioreactor system, bulk PBMCs from healthy donors and MM patients could expand 77-fold on average, and acquired enhanced cytotoxicity that positively correlated with the up-regulation of the NKp44 activating receptor. However, the expanded culture contained a significant proportion of $\mathrm{T}$ cells, necessitating further T-cell depletion prior to clinical use (61). Furthermore, purified $\mathrm{CD}^{+} 6^{+}$populations were positively selected from PBMCs of healthy individuals using CD56 magnetic microbeads, and cultured in X-VIVO 10 medium containing $10 \%$ human $\mathrm{AB}$ serum and $500 \mathrm{U} / \mathrm{ml} \mathrm{IL-2} \pm 10 \mathrm{ng} / \mathrm{ml} \mathrm{IL-15}$ for 2 weeks. Appreciable proliferation occurred 5-7 days from the start of the culture, although with remarkable donor-to-donor variability. Expansion of $\mathrm{CD}^{+}{ }^{+} \mathrm{CD} 56^{+} \mathrm{NK}$-like T cells was two to three times greater than that of $\mathrm{CD}^{-}{ }^{-} \mathrm{CD} 56^{+} \mathrm{NK}$ cells and was not affected by IL-15. Compared with the NK-92 cell line, ex vivo expanded $\mathrm{CD}_{5}{ }^{+}$cells had lower lytic activity against both K562 and Raji target cells (66).

The natural nicotinamide adenine dinucleotide (NAD) ${ }^{+}$precursor and $\mathrm{NAD}^{+}$-dependent enzyme inhibitor nicotinamide (NAM) has been recently shown to induce a 60 - to 80 -fold NK-cell expansion when added to feeder-free cultures containing IL-2 and IL-15 (82). In this study, NAM also affected NK cell anti-tumor capabilities and trafficking properties by modulating expression of CD200R and PD1, two immune regulatory receptors that transmit inhibitory signals upon interaction with cognate ligands on cancer cells. In addition, NAM promoted surface expression of L-selectin, an adhesion molecule mediating interactions with vascular endothelium and lymph nodes.

\section{CD3 $^{+}$T-Cell Depletion with or without CD56 Enrichment}

The CE-approved, partially automated Clini-MACS ${ }^{\circledR}$ instrument from Miltenyi allows the enrichment of NK cells under GMPcompliant conditions (58). After a single step of magnetic $\mathrm{CD}^{+}$ T-cell depletion, PBMCs are stimulated and expanded with irradiated autologous cells in the presence of OKT3 and IL-2, resulting in a highly pure population of functional $\mathrm{CD} 3^{-} \mathrm{CD} 16^{+} \mathrm{CD} 56^{+}$ NK cells that lack cytotoxicity against allogeneic non-tumor cells (83) (Table 1). Immunomagnetic $\mathrm{CD}^{+}{ }^{-}$-cell depletion with either the 2.1 or the 3.1 programs can be combined with CD56cell enrichment (84). When $\mathrm{CD}^{+} 6^{+}$cells are magnetically isolated, the expansion of $\mathrm{CD}^{+}{ }^{+} \mathrm{CD} 56^{+}$cells in culture may outweigh that of $\mathrm{CD}^{-}{ }^{-} \mathrm{CD} 56^{+}$cells, since $\mathrm{CD}^{+}$cells are not depleted upfront (66). Furthermore, CD56 expansion in cultures supplemented with IL-2, either alone or in combination with IL-15, shows 
TABLE 1 | Current GMP-compliant NK-cell manufacturing methods are detailed.

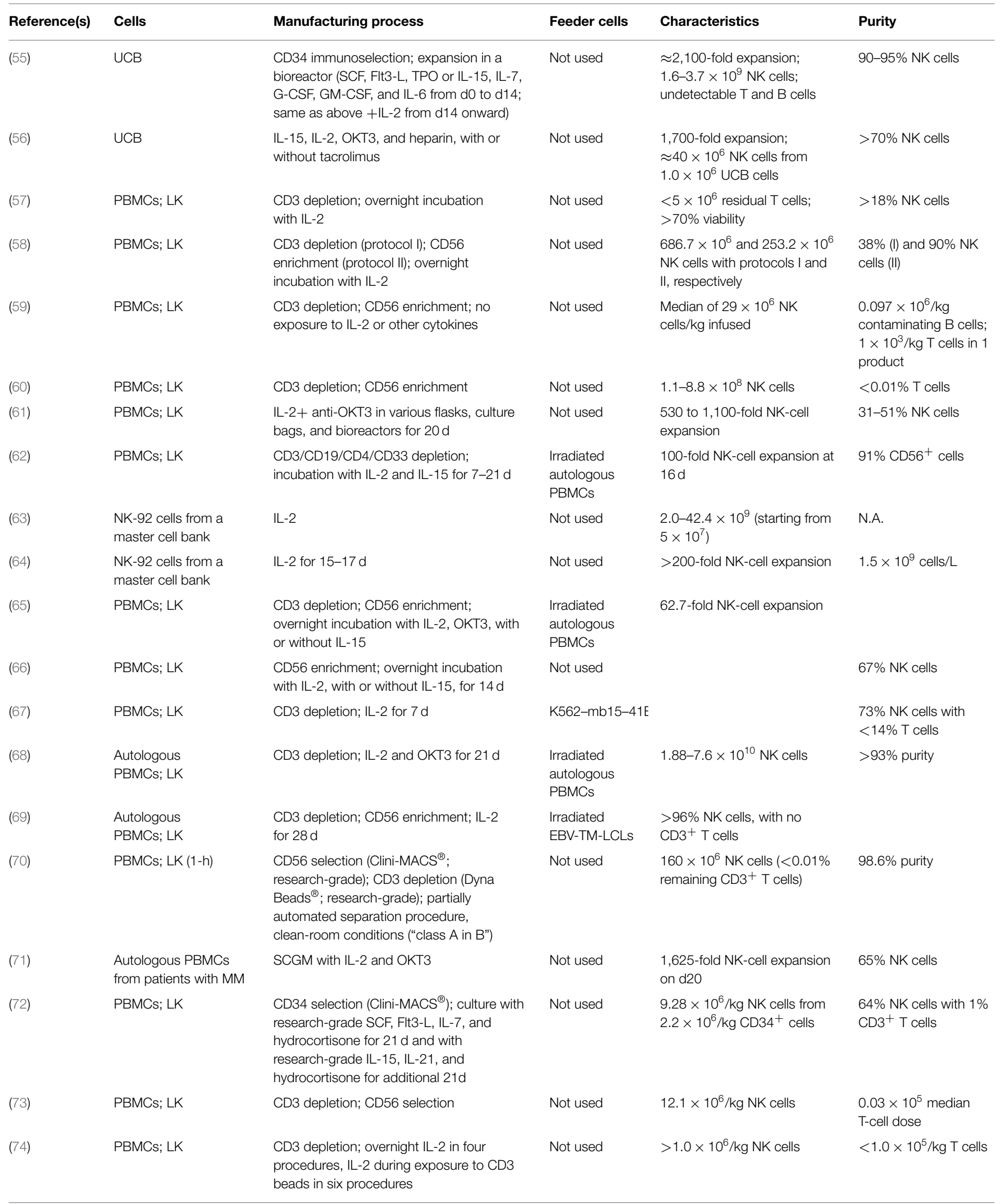


TABLE 1 | Continued

\begin{tabular}{|c|c|c|c|c|c|}
\hline Reference(s) & Cells & Manufacturing process & Feeder cells & Characteristics & Purity \\
\hline$(75)$ & PBMCs; LK & CD3 depletion; CD56 selection & Not used & $\begin{array}{l}5.0 \times 10^{6} / \mathrm{kg} \mathrm{NK} \text { cells in } 77 \% \\
\text { of patients }\end{array}$ & 93.5\% purity \\
\hline$(76)$ & PBMCs; LK & CD3 depletion; IL-2 for 8-16 h & Not used & $21.0 \times 10^{6} / \mathrm{kg} \mathrm{NK}$ cells & $43 \%$ purity \\
\hline (77) & PBMCs; LK & $\begin{array}{l}\text { NK-cell priming with CNDO-109 lysate } \\
\text { (derived from a leukemia cell line, CTV-1) }\end{array}$ & Not used & $<10^{4}$ residual $\mathrm{T}$ cells & \\
\hline (78) & PBMCs; LK & CD3 depletion; 1,000 U/ml IL-2 & Not used & $\begin{array}{l}\text { Median } 26 \% \text { haploidentical } \\
\text { NK cells; three dose levels }\end{array}$ & Median viability $>95 \%$ \\
\hline
\end{tabular}

PBMC, peripheral blood mononuclear cells; LK, leukapheresis; d, day; UCB, umbilical cord blood; SCGM, stem cell growth medium; MM, multiple myeloma.

substantial inter-donor variability. Each of the above programs translates into differences in depletion efficiency and recovery of NK cells, with NK purification being improved after sequential processing with the Clini-MACS T-cell depletion programs D2.1 and D3.1. Not unexpectedly, absolute NK-cell numbers after manipulation may correlate with the pre-harvest NK-cell content of the PB (85), implying that donors with high NK-cell counts are likely to provide NK-cell products with the highest cell numbers. A clinical-scale procedure to isolate NK cells for infusion in pediatric patients was developed under clean-room conditions (70). One-hour leukapheresis collections from unstimulated healthy donors were used to positively select $\mathrm{CD} 56^{+}$cells and negatively deplete $\mathrm{T}$ cells, ultimately leading to cell therapy products enriched in NK cells and containing only $0.09 \%$ remaining T cells. A similar procedure consisting of two rounds of CD3 depletion and one round of CD56 selection has been used to obtain clinically applicable numbers of NK cells for immunotherapy (86). In that study, NK cells were expanded with IL-2 for 10-14 days to achieve the desired cell dose for potential clinical application in three children with relapsed or refractory leukemia after haploidentical HSCT.

Natural killer cells can also be expanded with irradiated autologous feeder cells, IL-2, IL-15, and anti-CD3 antibodies. Using these systems, NK cells acquire a CD $56{ }^{\text {int }} \mathrm{CD} 16{ }^{\text {int }}$ phenotype and increase an average of 117-fold in 3 weeks (65). IL-2 and IL-15 mediate better NK expansion and viability compared with cultures nurtured with IL-2 only. Importantly, the number of residual contaminating T cells may be significantly lower after NK-cell exposure to IL-2 and IL-15 compared with IL-2 alone. NK cells activated with IL-2 and IL-15 may display higher cytotoxicity against K562 cells when kept in culture at a low effector-to-target ratio (66). In order to selectively expand alloreactive NK cells, $\mathrm{KIR}^{+}$ cells can be isolated from Clini-MACS-purified CD $3^{-} \mathrm{CD}_{5} 6^{+} \mathrm{NK}$ cells using cell sorting, and then stimulated with the same cytokine cocktail (65). GMP-sorted and expanded single $\mathrm{KIR}^{+}$cells were cytolytic against AML blasts, an effect that was more pronounced than that mediated by bulk NK cells in an HLA-mismatched setting.

Interleukin-21 can offer theoretical advantages for the expansion of NK cells. The temporal exposure of IL-2/IL-15-stimulated NK cells to IL-21 determines the extent to which NK-cell proliferation and function are promoted (87). Specifically, NK cells stimulated with IL-21 during the first week of culture were shown to have strong proliferative response and cytotoxic activity compared with control cultures. The short-term expanded
NK cells had longer telomeres than NK cells maintained with IL-21 continuously. IL-21 has also been used in combination with IL-15 to activate HLA-mismatched NK cells derived from $\mathrm{CD}_{3}{ }^{+}$hematopoietic progenitors with SCF, Flt3-L, IL-15, and hydrocortisone (72).

\section{Use of Feeder Cells}

While the minimum necessary NK-cell number for therapeutic efficacy is still controversial, the consistent generation of large amounts of functional cells is crucial to develop clinical protocols of adoptively transferred NK cells. Different feeder cell types have been used to expand NK cells, including irradiated PBMCs, EBV-transformed lymphoblastoid cell lines (EBV-LCL), genemodified K562 cells expressing NK cell-stimulatory molecules such as 41BB-ligand and mbIL-15 (67). Compared with IL-2mediated activation, NK-cell expansion in the presence of feeder cells may also result in increased anti-tumor cytotoxic functions, with comparable in vivo survival $(69,88)$.

K562 cells were transduced with constructs encoding mbIL-15 (IL-15 $+\mathrm{CD} 8 \alpha$ ) and human 41BB-ligand (both containing green fluorescent protein). NK-cell recovery was 21.6-fold after 7 days of culture and increased to 152-fold and 277-fold after 14 and 21 days of culture, respectively. Importantly, the median recovery of NK cells was comparable when mononuclear cells from patients with acute leukemia were used in the co-culture. The expanded NK cells were cytotoxic against both AML cell lines and primary AML blasts. When compared with IL-2-stimulated NK cells, the cytotoxicity of expanded NK cells was greater at all effector-totarget ratios (67). In a mouse model of AML, multiple injections of expanded NK cells vigorously suppressed leukemia growth, with some mice achieving long-term control of the disease in the absence of xenogeneic GVHD. Finally, a master cell bank of K562mb15-41BBL cells was established following GMP guidelines. The transduced NK cells were used to expand NK cells from leukapheresis collections at a 1:10 NK cell-transduced K562 cell ratio. The expansion of NK cells ranged from 33- to 141-fold after 7 days in culture. The overall yield of NK cells was higher than that observed in small-scale experiments.

A GMP-compliant NK-expansion methodology was also applied to patients with metastatic melanoma or renal cell carcinoma. A 278- to 1,097-fold NK-cell expansion was obtained when OKT3-loaded, 30-Gy-irradiated autologous PBMCs were used as feeders in AIMV medium containing $10 \%$ human AB serum and $600 \mathrm{U} / \mathrm{ml} \mathrm{IL-2}$ for 21-26 days. Following adoptive transfer to patients treated with a lymphodepleting regimen, expanded NK 
cells persisted for multiple days, likely representing the majority of NK cells in the circulation 1 week after infusion (68). Autologous PBMCs have also been used as feeders for the expansion of NK cells from healthy donors. Feeder cells obtained from the NKdepleted fraction of donor leukapheresis collections were used at a 10:1 feeder/NK-cell ratio for a GMP-compliant expansion procedure in Baxter LifeCell culture bags containing SCGM CellGro medium, 5\% human AB serum, and $200 \mathrm{U} / \mathrm{ml}$ IL-2 with or without IL-15 supplementation. This protocol was successful in propagating cultured NK cells, which expanded $117 \pm 20$-fold after 19 days in the presence of $10 \mathrm{ng} / \mathrm{ml} \mathrm{IL-15}$ (65). More recently, a similar NK-cell expansion efficiency was reported when NK cells from healthy donors or patients with ALL in CR were co-cultured with autologous PBMCs in CellGro SCGM medium containing IL-2 and IL-15 (respectively, 34.9- vs. 39.5-fold average expansion after 14 days) (89).

Allogeneic PBMCs have been used as feeder cells for large-scale expansion of clinical-grade NK cells $(62,69)$. Allogeneic PBMCs and NK cells were co-cultured in X-VIVO 20 medium containing $500 \mathrm{U} / \mathrm{ml} \mathrm{IL-2} \mathrm{(69),} \mathrm{or} 100 \mathrm{U} / \mathrm{ml} \mathrm{IL-2}$ and $10 \mathrm{ng} / \mathrm{ml} \mathrm{IL-15} \mathrm{(62).}$ In these studies, a similar 80 - to 100 -fold NK-cell expansion was achieved in 14-15 days. In an interesting study from Kim and colleagues, autologous PBMC feeders from cancer patients or PBMCs from healthy donors were compared (90). Co-cultures containing PBMCs from healthy donors could more efficiently propagate NK cells than those containing PBMCs from cancer patients (respectively, 300- vs. 169.4-fold average expansion after 14 days).

Pittari and colleagues described a novel technique for selection, deposition, and high-efficiency cloning of individual NK cells displaying surface receptor repertoires of choice. Cells were selected by FACS, deposited into $U$-shaped polystyrene 96-well plates (one cell per well) containing CellGro SCGM medium supplemented with $10 \%$ human $\mathrm{AB}$ serum and without exogenous cytokines. Propagation of NK clones from single cells was driven by trans-presentation of IL-15 by BaF/3 pre-B-lymphocytes double transfected with human IL-15R $\alpha$ and human IL-15 (BaF/3 IL-15R $\alpha /$ IL-15). Additional feeder cells were EBV-BLCL (JY) and PBMCs from three allogeneic donors (91). In this pre-clinical design, the technique allowed for prompt propagation of NK clones from NK-cell populations potentially involved in the control of leukemia relapse, i.e., expressing the KIR2DS1 activating receptor (22), regardless of their frequency (Figure 1). After 3 weeks, propagated NK clones typically reached $0.25-4 \times 10^{6}$ cells, with an overall cloning efficiency as high as $35-40 \%$.

The replicative potential of NK cells expanded with genetically modified K562 cells can be further enhanced by enforcing the expression of human telomerase reverse transcriptase (TERT) gene (92). After stimulation with K562 cells for 1 week, NK cells were transfected with a retroviral vector containing human TERT. At variance with the control cultures that underwent replicative senescence after 16 population doublings, TERT-NK cells continued to expand in vitro for more than 1,000 days, if periodically re-stimulated with K562 cells. However, NK cells accumulated genetic changes at late time-points, including gain in genes on chromosome 1 and losses in genes on chromosome 16, suggesting that genetic instability may be a limiting factor in immortalization of NK cells.

Gas-permeable cell culture devices (G-Rex) are being evaluated for the expansion of T cells and tumor cells. In these systems, gas exchange across the base of the culture allows increased volumes of medium per unit area, augments the rate of cell expansion, and decreases cell death, minimizing cell manipulation. Using this strategy, up to $19 \times 10^{9}$ functional NK cells were produced starting from leukapheresis products, within 8-10 days of culture (93). The contaminating T cells mostly comprised $\mathrm{CD}^{+}{ }^{+} \mathrm{T}$ cells and could be removed by magnetic depletion. When compared with conventional gas-permeable bags, the G-Rex yielded higher fold expansions of NK cells, requiring no interim manipulation or feeding during the culture period. The NK cells were viable and functional, even after 12 months of cryopreservation.

\section{Use of Cord Blood and Other Stem Cell Sources to Expand NK Cells}

Umbilical cord blood is an emerging source of NK cells for clinical applications and also provides an in vitro system to analyze NK development (4). Banked UCB units represent an ideal "off-theshelf" source of NK cells for adoptive immunotherapy. Importantly, NK cells from PB and UCB differentially express cytokine receptors, with IL-15R $\alpha$ being preferentially detected on UCB NK cells and IL-12R $\beta 1$ and IL- $18 \alpha$ receptors being primarily found on PB NK cells $(94,95)$. The combination of IL-15 and IL-18 optimally stimulates the proliferation of UCB NK cells and potentiates the release of IFN- $\gamma$ and TNF- $\alpha$. The lower responsiveness of UCB NK cells to IL-2 observed in these studies may be the result of lower expression of IL-2 receptors and of decreased phosphorylation of STAT5 as compared with PB NK cells. This implies that, at variance with $\mathrm{PB}$ NK cells that are fully activated by IL-2 alone, UCB NK cells may require additional cytokine stimuli (96). For instance, the addition of tacrolimus and low-molecular-weight heparin significantly enhances NK-cell expansion induced by IL2, IL-15, and anti-CD3 mAbs (56). Using this protocol, approximately $40 \times 10^{6} \mathrm{NK}$ cells were obtained from $1 \times 10^{6}$ unmanipulated UCB cells, in the absence of feeder cells, corresponding to $>1,000$-fold expansion. Bioreactors have been used to expand UCB-derived NK cells as well. This approach resulted into the generation of a clinically relevant dose of NK cells with $>2,000$ fold expansion, purity of $>90 \%$, high expression of activating receptors and cytolytic activity against K562 leukemia cells (55).

It has been shown that UCB-derived NK cells actively migrate to the BM, spleen, and liver $24 \mathrm{~h}$ after infusion in NOD-SCID-IL$2 \mathrm{R} \gamma$-null mice (97). NK cells were differentiated in 3-4 weeks from $\mathrm{CD} 34^{+}$hematopoietic progenitors exposed to multiple cytokines, and were found to express CXCR4, CXCR3, and CCR6, which likely accounted for their ability to home to BM and inflamed tissues. A single NK-cell infusion combined with in vivo low-dose IL-15 resulted in inhibition of leukemia growth and prolongation of mice survival.

Finally, human embryonic stem cells (ESCs) as well as induced pluripotent stem cells (iPSCs) are potential sources of phenotypically mature and functional NK cells (98). ESCs and iPSCs were first used to produce hematopoietic progenitors with the "spin embryonic body (EB)" method, in which defined numbers 


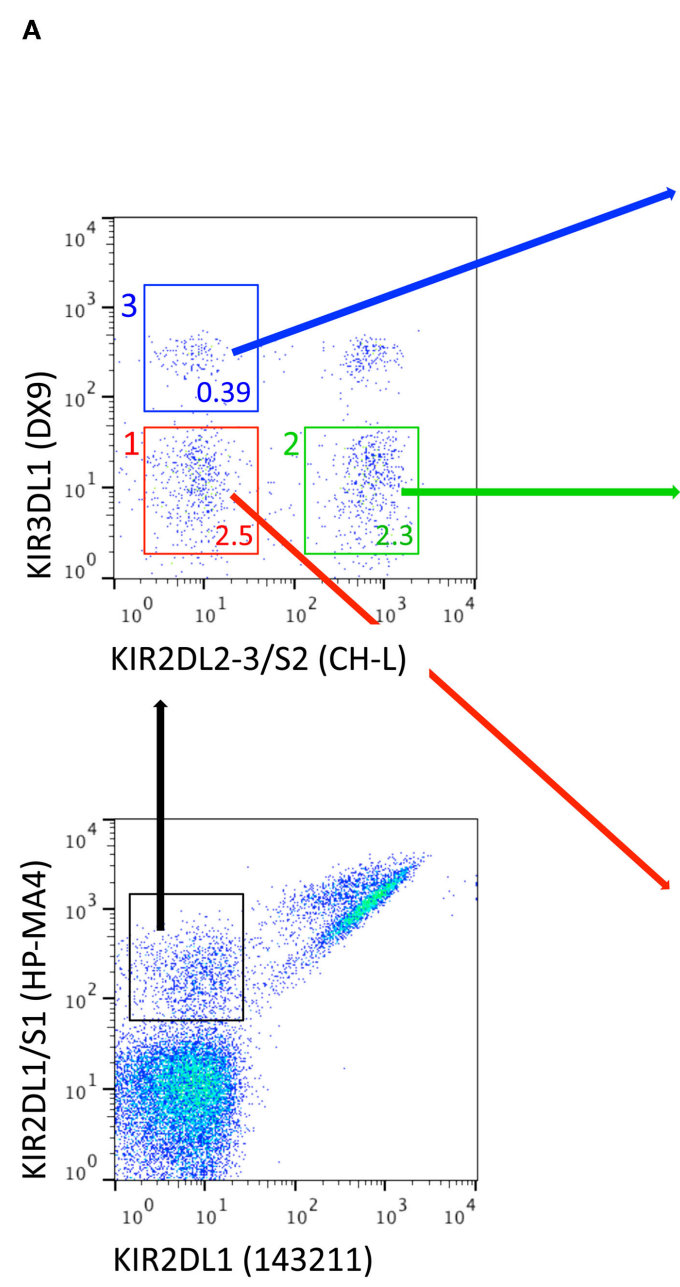

FIGURE 1 | Generation of NK clones from individual NK cells with specific KIR receptor repertoires. (A) Flow cytometry representation of NK-cell subsets defined by a combination of four anti-KIR mAbs. In this example, subsets used for FACS-assisted single-cell deposition express 2DS1, either alone (subset 1, red) or in combination with at least one receptor among 2DL2, L3, and S2
B

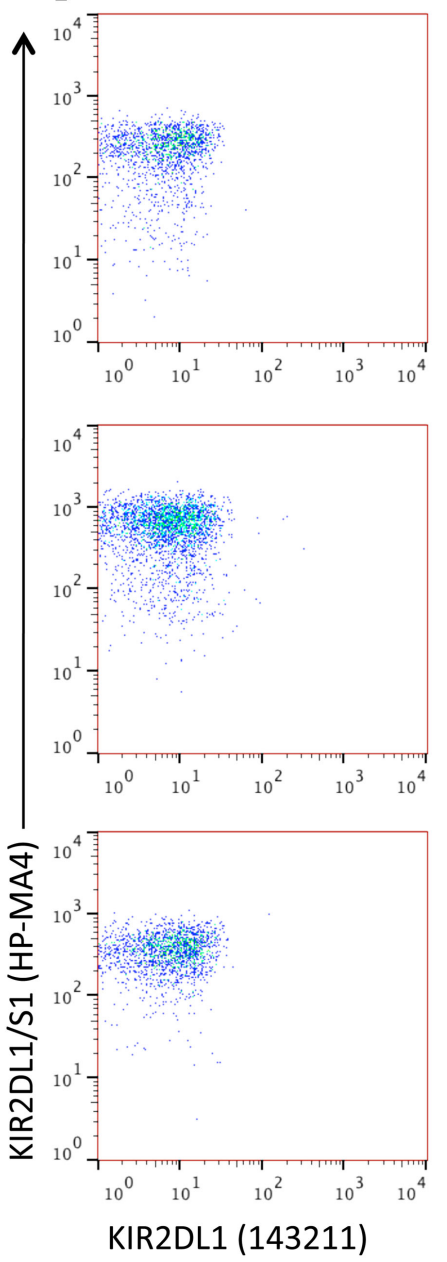

(subset 2, green) or 3DL1 (subset 3, blue). The percent frequency of NK-cell subsets is indicated. (B) Representative NK clones obtained after 3-week in vitro propagation in the presence of $\mathrm{IL}-15$ trans-presentation. E115: 2DS1 ${ }^{\text {pos }}$; E78: 2DS1 ${ }^{\text {pos }} / \mathrm{CH}^{\mathrm{Los}}$; E86: $2 \mathrm{DS} 1^{\text {pos }} / 3 \mathrm{DL} 1^{\text {pos }}$. For E78, specific $\mathrm{KIR}(\mathrm{s})$ can be identified by real-time $\mathrm{RT}$-qPCR.

of cells were spin-aggregated in serum-free medium. This strategy removed the need for murine stromal support, and led to hematopoietic cell development and proliferation. Spin EBderived cells were then tested in a feeder-free and serum-free system containing NK-cell promoting cytokines, i.e., IL-3, IL-7, IL-15, SCF, and Flt3-L. Within the first 2 weeks of culture, both non-adherent $\mathrm{CD} 31^{+}$endothelial cells and $\mathrm{CD} 73^{+}$mesenchymal stromal cells were detected. Importantly, NK cells developed in similar numbers, phenotype, and functional characteristics as those differentiated with the use of murine stromal cells (98). Artificial APCs engineered to express mbIL-21 additionally expanded NK cells. As the expected requirement for NK-cell adoptive transfer protocols is approximately $2 \times 10^{7} \mathrm{NK}$ cells $/ \mathrm{kg}$ (see below), genetically modified APCs allow the use of a starting population of $<10^{6} \mathrm{ESCs} / \mathrm{iPSC}$ per patient, corresponding to a lower number of cells compared with that required for NK-cell expansion from the PB.

\section{Use of Genetically Engineered NK Cells}

Although lentiviral (LV) vectors have been successfully used to transduce both T cells and NK-cell lines, LV transduction of both freshly isolated and ex vivo-expanded NK cells may be challenging. Chimeric antigen receptors (CARs) are synthetic engineered receptors that target surface molecules in their native conformation, independent of MHC and of antigen processing by the target cells (99). The generations of CARs are typically classified based on the intracellular signaling domains, with first-generation CARs including only $\mathrm{CD} 3 \zeta$, second-generation CARs including one single costimulatory domain and third-generation CARs including two costimulatory domains, such as CD28 and 41BB.

Natural killer cells can be transduced with mRNA encoding for anti-CD19 CARs. The expression of a receptor containing CD3 $\zeta$ and $41 \mathrm{BB}$ signaling molecules (anti-CD19-BB- $\zeta$ ) was induced in human NK cells with a clinical-grade electroporator. The cytotoxicity of the transfected NK cells was evaluated both in vitro 
and in a mouse model of leukemia. Receptor expression was already detectable $6 \mathrm{~h}$ after electroporation, reaching maximum levels at 24-48 h. Toxicity against CD19-expressing targets was specifically observed at $96 \mathrm{~h}$. Median anti-CD19-BB- $\zeta$ expression $24 \mathrm{~h}$ after electroporation was 40.3 and $61.3 \%$ in freshly purified and in expanded NK cells, respectively. NK cells expressing antiCD19-BB- $\zeta$ secreted IFN- $\gamma$ in response to CD19 ${ }^{+}$target cells and had enhanced cytotoxicity against B-cell malignancies (100). Transduced NK cells were consistently more cytotoxic than nontransduced NK cells. A large-scale, GMP-compliant protocol was also developed and showed that median percentage of genetically modified NK cells with receptor expression was $82 \%$ after $24 \mathrm{~h}$. NK cells transfected under these conditions exerted in vivo cytotoxicity in NSG mice with B-cell leukemia, and suppressed leukemia progression compared with mice inoculated with mocktransfected NK cells (100). Interestingly, NK cells can acquire anti-CD19 CARs from donor cells via trogocytosis (101). When co-cultured with live K562 cells transduced to express anti-CD19BB- $\zeta$, NK cells acquired anti-CD19 CARs, peaking at $1 \mathrm{~h}$ and declining thereafter. NK cells displayed enhanced degranulation in response to leukemia cell lines compared with NK cells cocultured with control cells.

Genetically modified NK-cell lines, such as NK-92 cells, have been tested for in vitro and in vivo efficacy against MM. IL2-independent derivatives of NK-92 cells, i.e., NK-92MI cells, have been transduced with a first-generation CAR targeting CD138, an integral membrane protein expressed on differentiated plasma cells (102). Genetically modified NK-92MI cells harbored a CAR consisting of an anti-CD138 single-chain variable fragment $(\mathrm{scFv})$ fused to $\mathrm{CD} 3 \zeta$ chain. The retargeted NK cells (NK-92MI-scFv) released IFN- $\gamma$ and granzyme-B, and lysed CD138-expressing MM cell lines. When assayed in a xenograft NOD-SCID mouse model, transduced NK cells exerted more potent anti-tumor activity toward CD138-expressing MM cells than NK-92MI-mock. Importantly, NK cells could be detected in the MM microenvironment more than 20 days after their adoptive transfer.

CS1 is another surface protein highly expressed on MM cells and is amenable to targeting with CS1-specific CARs (103). CS1 co-localizes with CD138 on polarized plasma cells where it promotes adhesion, clonogenic growth, and tumorigenicity. Compared with mock-transduced NK cells, CS1-CAR-transduced NK cells had increased cytotoxic activity against CS1-expressing MM cells and showed heightened IFN- $\gamma$ production. In an orthotopic MM xenograft model, adoptively transferred CS1-CAR-NK-92 cells suppressed the growth of human IM9 MM cells and significantly prolonged mouse survival (103). Overall, studies with CAR-NK cells point to the efficacy of this approach. The safety profile of CAR-NK cells may be advantageous compared with that of CAR-T cells, because of lack of in vivo clonal expansion and cytokine storm. Also, CAR-NK cells should not induce GVHD, while potently mediating GVL effects.

Natural killer cells can also be transduced to express mbIL-15 (104). Compared with NK cells expressing wild-type IL-15, mbIL15 NK cells secreted low amounts of IL-15 in culture supernatants. Membrane-bound IL-15 appeared to be mostly occupying autologous receptors, suggesting that mb-IL-15 preferentially stimulates cells in cis, i.e., by direct binding to receptors expressed in the same cell. Genetically modified NK cells were maintained and expanded in culture without exogenous IL-2. When tested in vitro and in vivo, mbIL-15 NK cells displayed enhanced survival and cytotoxicity, being capable of inhibiting the growth of AML and sarcoma cells in NOD-SCID IL-2R $\gamma$-null mice.

A complementary approach to existing methods of genetic modification of NK cells is offered by a retroviral vector-based, gene transfer protocol (105). Using a SF $\alpha 11 \mathrm{GFP}$ viral vector, transduced NK cells were visible as GFP-expressing cells by fluorescence microscopy. The median transduction efficiency after one or two rounds of transduction was 27 and $47 \%$, respectively. On day 21 of culture, transduction efficiencies averaged 52 and $75 \%$, respectively. The gene transfer procedure did not affect NKcell phenotype or function, suggesting that retroviral vectors can be successfully applied to immunotherapy trials.

Clinical experience with CAR-engineered NK cells is in its infancy (106). Two clinical trials are currently open with the aim at exploring the therapeutic benefit of haploidentical NK cells modified with anti-CD19 CARs in children with B-cell precursor ALL (ClinicalTrials.gov NCT00995137) and in children and adults with refractory ALL (ClinicalTrials.gov NCT01974479). In these studies, NK cells will be expanded by co-culture with irradiated K562 cells modified to express mbIL-15 and 41BB-ligand. The expanded NK cells will be then transduced with a signaling receptor that binds to CD19 (anti-CD19-BB- $\zeta$ ).

\section{Use of Expanded NK-Cell Lines}

Several malignant NK-cell lines have been established and used for clinical trials in China, Japan, and Western Countries, as reviewed elsewhere (107). A potential drawback of this approach is that differences in HLA molecules across different ethnicities may translate into the production of HLA-specific antibodies by the recipient. NK-92 cells, the most extensively characterized NK-cell line, were established in 1994 from the PB of a male Caucasian patient with non-Hodgkin lymphoma, are IL-2-dependent and harbor a CD2 ${ }^{+} \mathrm{CD} 56^{+} \mathrm{CD} 57^{+}$phenotype (108-112). The adoptive transfer of NK-cell lines has theoretical advantages related to lack of expression of inhibitory KIRs, lack of immunogenicity, and ease of expansion. The optimal conditions for large-scale ex vivo expansion of NK-92 cells were recently defined. The protocol uses X-VIVO 10 serum-free media, supplemented with $450 \mathrm{U} / \mathrm{mL}$ of pharmaceutical grade rhuIL-2, and $2.5 \%$ allogeneic or autologous human serum or plasma (64). Cells maintained in gas-permeable culture bag systems with regular addition of fresh supplemented media achieve $>200$-fold expansion in 15-17 days, from a starting population of $6.25 \times 10^{6}$ cells to approximately $1.5 \times 10^{9}$ total cells per $1 \mathrm{~L}$-culture. Patients with solid tumors or leukemia/lymphoma $(n=2)$ were treated with two infusions of escalating doses of NK-92 cells given $48 \mathrm{~h}$ apart, with no infusion-related or long-term side effects being observed (63). NK-92 cell doses ranged from $1 \times 10^{9}$ to $1 \times 10^{10}$ cells $/ \mathrm{m}^{2}$. The dose of $10^{10}$ cells $/ \mathrm{m}^{2}$ was considered the maximum expandable cell dose. NK-92 cells persisted in vivo for at least $48 \mathrm{~h}$, as shown by $\mathrm{Y}$ chromosome-specific PCR in two female patients. Some responses were observed in patients with lung cancer. Only one patient developed anti-HLA antibodies, despite the allogeneic nature of NK-92 cells. NK-92 cells (Neukoplast ${ }^{\circledR}$ ) will continue to be tested in patients with solid tumors, e.g., Merkel cell 
cancer and renal cell carcinoma, and with hematological malignancies ${ }^{1}$ (Table $\mathbf{1}$ ).

Since several decades, EBV-immortalized B-lymphoblastoid cells (EBV-BLCL) are known to robustly support NK cell in vitro expansion and anti-tumor activity (113-115). Escudier and colleagues used 35-Gy-irradiated LAZ 388 EBV-BLCL for the ex vivo expansion of $\mathrm{NK}$ cells from patients with metastatic renal cell adenocarcinoma. NK cells were initially cultured in V-bottom microplates, at a 4:1 feeder cell to NK-cell ratio, in DMEM medium supplemented with $200 \mathrm{U} / \mathrm{mL}$ IL-2. Two to five days before clinical use, NK cells were transferred to Baxter bags, where they received an additional $250 \mathrm{U} / \mathrm{ml}$ IL-2 boost. On average, expansion of cultured NK cells was limited to 50-fold after 21 days. However, some clinical responses were observed when autologous NK cells were used as consolidation treatment for patients in partial remission (116). Berg and co-workers described a GMPcompliant protocol involving a 20:1 EBV-BLCL feeder to NKcell ratio and $500 \mathrm{U} / \mathrm{ml}$ IL-2. This system allowed for a 300- to 930-fold NK-cell expansion. EBV-BLCL feeders prevalently drove such an extensive phenomenon, as the use of PBMCs in similar conditions yielded inferior results (69). Based on this protocol, a phase I clinical trial is currently investigating technical feasibility and clinical efficacy of large-scale NK infusions (up to $1 \times 10^{9} / \mathrm{kg}$ ) in cancer patients receiving bortezomib administered with the scope of increasing susceptibility of tumor cells to NKmediated lysis $(117,118)$.

K562 engineered to express mbIL-15 and 41BB-ligand (K562mb15-41BBL) may be used to efficiently propagate NK cells with enhanced anti-leukemia properties. NK cells typically reach a $>20$-fold expansion after 7 days of co-culture, and a $>1,000$ fold expansion after 3 weeks, with no concomitant $\mathrm{T}$ cell propagation $(67,119)$. NK cells from patients with MM may also efficiently grow when co-cultured with K562-mb15-41BBL (120). When grown in GMP-compliant gas-permeable static cell culture flasks (G-Rex), as many as 19 billion unmanipulated NK cells can be obtained in 8-10 days starting from 150 million NK cells (93). Importantly, K562-mb15-41BBL cells have been successfully used to expand NK cells transduced with an anti-CD19-BB$\zeta$ CAR, which display enhanced reactivity to $\mathrm{CD} 19^{+}$leukemia cells (119). Similar to K562-mb15-41BBL, K562 genetically modified to express mbIL-21, or to co-express the ligand for $41 \mathrm{BB}$ and the NKG2D ligand MICA (K562-4-1BBL-mMICA), have been shown to promote large-scale expansion of NK cells with enhanced anti-tumor in vitro reactivity (121-123).

\section{Impact of Expansion Methods on NK-Cell Function and Homing Potential}

There are theoretical concerns that extensive in vitro expansion may affect the replicative potential and long-term viability of in vivo-infused NK cells. For instance, both Fas expression and susceptibility to apoptosis are increased after culture of NK cells with IL-2 or with feeder cells (124). In addition, expanded NK cells down-regulate receptors required for homing into secondary lymphoid organs, such as CCR7, a member of the G

${ }^{1}$ http://www.conkwest.com/nk-92 protein-coupled receptor family, and CD62L. In line with this, NK cells expanded with genetically modified K562 cells were shown to predominantly express a $\mathrm{CD} 16^{+} \mathrm{CD} 56^{+}$phenotype, with no detectable CCR7 (125). To obviate this, NK cells have been cultured with genetically modified, IL-21/CCR7 expressing K562 cells. These culture conditions reportedly resulted into transfer of CCR7 to $80 \%$ of expanded NK cells by trogocytosis, a fast, contactdependent uptake of membrane fragments, and molecules from "donor" to "acceptor" cells (126). CCR7 conferred migratory properties to NK cells by enhancing lymph node homing upon adoptive transfer to athymic nude mice. NAM dose-dependently increases CD62L expression on IL-2/IL-15-stimulated NK cells (82). NK cells expanded with NAM displayed better in vitro cytotoxic activity against a variety of tumor cell lines, including leukemia cells, and enhanced homing, as well as in vivo persistence in NOD-SCID mice.

Recently, two GMP-grade NK cells products manufactured at different production assistance for cellular therapies (PACT) facilities were evaluated for homing characteristics, i.e., freshly activated (FA)-NK, used by the Minnesota group, and ex vivoexpanded (Ex)-NK, developed by the Baylor College of Medicine group $(93,127)$. Although the two preparations had phenotypic differences, cytotoxicity against NK-sensitive targets was similar. In vivo recovery after the infusion of thawed products was lower compared with the infusion of fresh NK cells. Whereas the negative impact of cryopreservation on FA-NK was rescued by overnight culture with IL-2, this strategy was less effective on Ex-NK cells, suggesting the need for optimized cell processing methods (127). NK cells could be detected at day 7 but failed to further expand between day 7 and day 14. Interestingly, higher numbers of functional NK cells with enhanced expression of NKG2A were recovered in mice infused with Ex-NK cells and given IL-15. The homing pattern of the two products was different, with higher numbers of NK cells being detected in the BM of mice given Ex-NK cells and IL-15 compared with Ex-NK cells and IL-2. Conversely, mice receiving FA-NK cells had more NK cells in the spleen when given IL-15. This study emphasizes the importance of continued cytokine stimulation for ex vivo-expanded cells, and suggests that differences in the manufacturing process affect in vivo homing and clinical efficacy of the NK-cell product.

\section{Clinical Trials with NK Cells in Hematological Malignancies}

\section{Autologous NK Cells}

Early clinical studies exploited LAK-based immunotherapy in the autologous setting. One hundred eight patients with refractory metastatic cancer received LAK cells generated from autologous PBMCs incubated with 1,000 U/ml IL-2 for 3-4 days. Systemic high-dose IL-2 was given to support LAK cells in vivo (128, 129). Objective tumor regression occurred in $22 \%$ of 106 evaluable patients. Median response duration was 10 months for eight patients achieving complete remission (CR). Further prospective studies assessing the therapeutic effects of high-dose IL-2 and LAK cells indicated a possible survival advantage for patients with melanoma treated with LAK cells (130). 
Immunotherapy with systemic IL-2 and autologous LAK cells was also given as consolidation treatment after autologous bone marrow transplantation (BMT). Sixteen patients with lymphoma received, 12-14 days post-transplantation, LAK cells generated from PBMCs incubated with IL-2 for 5 days (131). In a similar setting, NK cells obtained prior to transplant and activated with IL-2 for 6 days were infused into 12 patients with advanced cancer and post-BMT pancytopenia (132). Concomitant with NKcell transfer, sequential high to low-dose systemic IL-2 was also administered for over 90 days. This approach was well tolerated and resulted in the early enhancement of NK-cell activity in four recipients (132).

In general, trials with high-dose systemic IL-2 to support circulating LAK or NK cells were limited by severe and potentially lethal toxicities (e.g., vascular leak syndrome, oliguria, hypotension, myocardial infarction), counterbalancing the beneficial anticancer effects of LAK activity $(129,131,132)$. On the other hand, chronic low-dose IL-2 treatment was relatively well tolerated (133-135), but unable to activate NK cells as robustly as high-dose ex vivo IL-2, or IL-2 at concentrations that engage the intermediate-affinity IL-2 receptor on NK cells $(134,136,137)$. Subsequent studies sought to maximize NK-mediated anti-tumor effects. Ex vivo IL-2-activated NK-cell infusions were compared with supplemental intravenous IL-2 boluses on days 28 and 35 during daily subcutaneous IL-2 administration in patients with relapsed lymphoma or metastatic breast cancer. Both treatment conditions induced strong NK-cell anti-tumor reactivity, and boosted circulating cytokines, without any consistent impact on clinical outcome compared with matched patients from the Autologous Blood and Marrow Transplant Registry database (138).

The proliferation potential of NK cells isolated from cancer patients may be similar to that of NK cells from healthy donors, reassuring about the feasibility of manufacturing autologous NKcell products. Although autologous NK cells persist in vivo for at least 1 week after infusion, they express lower levels of NKG2D, a key activating receptor, and may necessitate in vitro re-activation with IL-2 to lyse tumor targets (68).

Collectively, the analysis of phase II immunotherapy studies with autologous NK cells failed to show efficacy (139). Several factors may have accounted for the disappointing results, including competition with the recipient's lymphocytes for cytokines and "space"; inhibition of autologous NK cells by self-MHC (30, 140, 141); chronic immunosuppression induced by the tumor on host immunity; and expansion of Treg cells by IL-2 (127). Autologous NK cells are currently being tested in patients with hematological malignancies and solid tumors (NCT00720785; Table 2) (142). In this trial, which is recruiting participants, patients will receive immune suppressive therapy with pentostatin, followed by bortezomib to sensitize tumor cells to NK cytotoxicity (143), escalating doses of autologous NK cells and IL-2.

\section{Allogeneic NK Cells}

Initial clinical trials on allogeneic T-cell depleted (TCD) haploidentical HSCT for patients with AML showed enhanced NKmediated cytotoxicity when KIR-HLA class I mismatch occurred (23). In 2005, Miller and co-workers administered haploidentical NK cells in a non-transplantation setting to 43 patients with advanced cancer. Three pharmacological regimens of different intensity were used to prevent immunological rejection (57). After a single leukapheresis, $\mathrm{CD}^{+} \mathrm{T}$ cells were depleted under GMP conditions using CD3 microbeads. The TCD product was activated overnight with IL-2 before infusion. NK cells were enriched to $40 \%$ on average after processing. The final IL-2-activated product contained an NK-cell dose of $8.5 \times 10^{6}$ cells $/ \mathrm{kg}$ of recipient's body weight and a final T-cell dose of $1.75 \times 10^{5}$ cells $/ \mathrm{kg}$. A lowintensity immune suppressive regimen was administered on an outpatient basis to the first 17 patients, followed by the infusion of escalating doses of NK cells. Importantly, no dose-limiting toxicity occurred in this patient cohort. Using RT-PCR primers for donorspecific MHC class I alleles, donor cells were shown to persist for 5 days and to comprise $<1 \%$ of circulating PBMCs, likely due to immune rejection. Alternative low-intensity (fludarabine alone) and high-intensity immune suppressive regimens (highdose cyclophosphamide and fludarabine) were subsequently used in seven patients with renal cell carcinoma and 19 patients with poor-prognosis AML, respectively. None of the patients given fludarabine alone engrafted with donor NK cells. By contrast, 8 of 15 evaluable patients with AML showed at least $1 \%$ engraftment of donor cells after NK-cell infusion. Overall, five patients achieved a morphological CR. Among the four patients with a KIR-ligand mismatch in the graft-versus-host direction, three achieved CR. This was paralleled by the observation that CR was obtained only in 2 of 15 patients without alloreactivity. Finally, IL-15 serum levels were significantly higher in patients receiving higher-intensity, lymphodepleting immune suppression, suggesting that a rise in endogenous IL-15 may be required for the in vivo expansion and persistence of infused NK cells.

Subsequent studies suggested the possibility that IL-2 administered after NK infusions also expands Treg cells, potentially interfering with in vivo NK-cell proliferation (76). To address this issue, IL-2 diphtheria toxin (IL-2DT) was administered to 15 patients with relapsed/refractory AML, 1 day before the enriched NK product (145). IL-2DT is a recombinant cytotoxic fusion protein composed of the amino acid sequences for diphtheria toxin followed by truncated amino acid sequences for IL-2. IL-2DT reportedly depletes IL-2 receptor $\alpha$-chain (CD25)-expressing cells, including Treg cells. In this study, three processing methods were used to prepare NK-cell products, including CD3 depletion alone, CD3 depletion followed by CD56 selection, and single-step CD3/CD19 depletion. Higher NK-cell doses were obtained after depletion of $\mathrm{CD}^{+}$and $\mathrm{CD} 19^{+}$cells from a 5 -h donor apheresis collection. Among the 42 patients who did not receive host Treg depletion, $21 \%$ achieved remissions. By contrast, Treg depletion with IL-2DT resulted in remissions at day 28 for eight of 15 patients (53\%). The magnitude of NK-cell expansion was also higher after Treg depletion. The ability of IL-2DT to deplete Treg cells was further supported by reductions in serum IL-35 concentrations 14 days after adoptive transfer. Finally, 7 out of 10 patients (70\%) with detectable donor NK cells attained CR by day 28 compared with only 1 of 5 patients (20\%) lacking detectable donor $\mathrm{NK}$ cells at day 7, suggesting that NK-cell persistence is required for clinical efficacy. Interestingly, this study showed no correlation between achievements of CR- and KIR-ligand mismatch. 
TABLE 2 | Completed and ongoing clinical trials with NK cells for patients with hematological malignancies are listed.

\begin{tabular}{|c|c|c|c|c|c|}
\hline Pts. & Diagnosis & NK-cell preparation & Status & Clinical site & $\begin{array}{l}\text { Reference(s)/ } \\
\text { NCI Identifier }\end{array}$ \\
\hline 10 & $\begin{array}{l}\text { Children with } \\
\text { MRD-negative AML }\end{array}$ & $\begin{array}{l}\text { Conditioning with cyclophosphamide and } \\
\text { fludarabine; inhibitory KIR-HLA-mismatched } \\
\text { NK cells to reduce relapse risk; } 6 \text { doses of } \\
\text { 1-million U/m } \mathrm{m}^{2} \text { IL-2 starting on day -1 }\end{array}$ & Published & $\begin{array}{l}\text { St Jude Children's Research } \\
\text { Hospital, Memphis, TN, USA }\end{array}$ & $(59)$ \\
\hline 6 & Leukemia, LY & $\begin{array}{l}\text { Immunotherapy with NK cells, } \\
\text { rituximab + GM-CSF; phase I }\end{array}$ & Completed (08/12) & $\begin{array}{l}\text { M.D. Anderson Cancer } \\
\text { Center, Houston, TX USA }\end{array}$ & NCT00383994 \\
\hline 30 & Lymphoma & CD56 selection & Published & Duke University, NC, USA & (144) NCT00586690 \\
\hline 22 & AML, MDS, JMML & $\begin{array}{l}\text { Haploidentical donor-derived NK cell infusion } \\
\text { and chemotherapy (CY, FLU, IL-2) }\end{array}$ & Completed (04/14) & $\begin{array}{l}\text { St Jude Children's Research } \\
\text { Hospital, Memphis, TN, USA }\end{array}$ & NCT00640796 \\
\hline 13 & AL, LY, MY & Allogeneic NK cells post-ABMT; phase I & Completed (06/12) & $\begin{array}{l}\text { Tufts Medical Center, Boston, } \\
\text { MA, USA }\end{array}$ & NCT00660166 \\
\hline 48 & $\begin{array}{l}\text { ALL, JMML, AML, } \\
\text { MDS, NHL }\end{array}$ & $\begin{array}{l}\text { Haploidentical NK cells after chemotherapy } \\
\text { with clofarabine, CY, and etoposide; IL-2; } \\
\text { phase I }\end{array}$ & Completed (03/13) & $\begin{array}{l}\text { St Jude Children's Research } \\
\text { Hospital, Memphis, TN, USA }\end{array}$ & NCT00697671 \\
\hline 13 & AML & $\begin{array}{l}\text { NK cells from haploidentical KIR-ligand } \\
\text { mismatched donors after FLU/CY } \\
\text { chemotherapy, followed by IL-2; phase I }\end{array}$ & Published & Univ. of Bologna, Italy & $(75)$ \\
\hline 14 & BCP-ALL & Gene-modified NK cells; phase I & Not recruiting & $\begin{array}{l}\text { St Jude Children's Research } \\
\text { Hospital, Memphis, TN, USA }\end{array}$ & NCT00995137 \\
\hline 86 & $\begin{array}{l}\text { Hematological } \\
\text { malignancies }\end{array}$ & $\begin{array}{l}\text { NK cells after MRD or MUD HSCT in children } \\
\text { with solid tumors and leukemia; phase I }\end{array}$ & Recruiting & $\mathrm{NCl}$, Bethesda, MD, USA & NCT01287104 \\
\hline 13 & $\begin{array}{l}\text { Hematological } \\
\text { malignancies }\end{array}$ & NK cells and UCBT; phase I & Recruiting & $\begin{array}{l}\text { M.D. Anderson Cancer } \\
\text { Center, Houston, TX, USA }\end{array}$ & NCT01619761 \\
\hline 90 & High-risk AML & $\begin{array}{l}\text { Donor NK cells and IL-2 before HSCT with } \\
\text { CD34 }{ }^{+} \text {cells and RIC; phase I/II }\end{array}$ & Active, not recruiting & $\begin{array}{l}\text { Masonic Cancer Center, } \\
\text { University of Minnesota }\end{array}$ & NCT00303667 \\
\hline 6 & $\begin{array}{l}\mathrm{CD} 2 \mathrm{O}^{+} \text {relapsed } \\
\mathrm{NHL} \text { or } \mathrm{CLL}\end{array}$ & $\begin{array}{l}\text { Allogeneic NK cells; CY, FLU and rituximab } \\
\text { followed by IL-2; phase I/II }\end{array}$ & Published & $\begin{array}{l}\text { Masonic Cancer Center, } \\
\text { University of Minnesota }\end{array}$ & $(76)$ \\
\hline 6 & $\begin{array}{l}\text { Relapsed NHL or } \\
\text { CLL }\end{array}$ & $\begin{array}{l}\text { Donor NK cells, rituximab, IL-2 and } \\
\text { chemotherapy; phase I/II }\end{array}$ & $\begin{array}{l}\text { Terminated early [failure to } \\
\text { meet primary outcome } \\
\text { (NK expansion)] }\end{array}$ & $\begin{array}{l}\text { Masonic Cancer Center, } \\
\text { University of Minnesota }\end{array}$ & NCT00625729 \\
\hline 47 & $\begin{array}{l}\text { Hematological } \\
\text { malignancies }\end{array}$ & $\begin{array}{l}\text { Donor NK cells after haploidentical HSCT; } \\
\text { phase I/II }\end{array}$ & Completed (02/13) & $\begin{array}{l}\text { Asan Medical Center, Seoul, } \\
\text { Korea }\end{array}$ & NCT00823524 \\
\hline 10 & MM & $\begin{array}{l}\text { In vitro-expanded haploidentical NK cells; } \\
\text { phase I/II }\end{array}$ & Recruiting & $\begin{array}{l}\text { University Hospital, Basel, } \\
\text { Switzerland }\end{array}$ & NCT01040026 \\
\hline 15 & $\begin{array}{l}\text { Hematological } \\
\text { malignancies (and } \\
\text { solid tumors) }\end{array}$ & $\begin{array}{l}\text { Pre-emptive NK-DLI early after HSCT; } \\
\text { phase I/II }\end{array}$ & Active, not recruiting & $\begin{array}{l}\text { University Hospital, Basel, } \\
\text { Switzerland }\end{array}$ & NCT01386619 \\
\hline 33 & $\begin{array}{l}\text { High-risk AML in CR, } \\
\text { not eligible for HSCT }\end{array}$ & $\begin{array}{l}\text { CNDO-109-activated allogeneic NK cells; } \\
\text { phase I/II }\end{array}$ & $\begin{array}{l}\text { Ongoing; preliminary } \\
\text { results ( } 7 \text { patients) } \\
\text { presented at } 2014 \mathrm{ASH} \\
\text { Meeting }\end{array}$ & United States (multi-center) & $\begin{array}{l}\text { NCT01520558 and } \\
\text { ref. (77) }\end{array}$ \\
\hline 30 & $A L, M D S$ & $\begin{array}{l}\text { HLA-haploidentical NK cells following } \\
\text { salvage chemotherapy for patients who have } \\
\text { relapsed or persistent leukemia following } \\
\text { allogeneic HSCT; phase II }\end{array}$ & Ongoing, not recruiting & $\begin{array}{l}\text { Memorial Sloan-Kettering } \\
\text { Cancer Center, NY, USA }\end{array}$ & NCT00526292 \\
\hline \multirow[t]{2}{*}{2} & Relapsed ALL & $\begin{array}{l}\text { Haploidentical NK cells + epratuzumab and } \\
\text { low-dose IL-2; phase II }\end{array}$ & Terminated (slow accrual) & $\begin{array}{l}\text { M.D. Anderson Cancer } \\
\text { Center, Houston, TX, USA }\end{array}$ & NCT00941928 \\
\hline & & & & & $(145)$ \\
\hline 34 & $\mathrm{NHL}, \mathrm{CLL}$ & $\begin{array}{l}\text { Lymphodepleting chemotherapy with } \\
\text { rituximab and allogeneic NK cells; phase II }\end{array}$ & Recruiting & $\begin{array}{l}\text { Masonic Cancer Center, } \\
\text { University of Minnesota }\end{array}$ & NCT01181258 \\
\hline 43 & AML, MDS & $\begin{array}{l}\text { NK-cell-based non-myeloablative } \\
\text { haploidentical HSCT; phase II }\end{array}$ & Recruiting & $\begin{array}{l}\text { Masonic Cancer Center, } \\
\text { University of Minnesota }\end{array}$ & NCT01370213 \\
\hline 6 & CML & $\begin{array}{l}\text { NK cells and non-myeloablative HSCT; } \\
\text { phase II }\end{array}$ & Completed (11/14) & $\begin{array}{l}\text { M.D. Anderson Cancer } \\
\text { Center, Houston, TX, USA }\end{array}$ & NCT01390402 \\
\hline
\end{tabular}


TABLE 2 | Continued

\begin{tabular}{|c|c|c|c|c|c|}
\hline Pts. & Diagnosis & NK-cell preparation & Status & Clinical site & $\begin{array}{l}\text { Reference(s)/ } \\
\mathrm{NCl} \text { Identifier }\end{array}$ \\
\hline 46 & MDS & $\begin{array}{l}\text { Decitabine and vorinostat conditioning } \\
\text { followed NK cell infusion and IL-2; phase II }\end{array}$ & Recruiting & $\begin{array}{l}\text { Masonic Cancer Center, } \\
\text { University of Minnesota }\end{array}$ & NCT01593670 \\
\hline 18 & $\begin{array}{l}\text { Refractory/relapsed } \\
\text { AML }\end{array}$ & $\begin{array}{l}\text { Neukoplast }{ }^{\mathrm{TM}}(\mathrm{NK}-92) ; 1-5 \times 10^{9} / \mathrm{m}^{2} \\
\text { phase I }\end{array}$ & Recruiting & Conkwest, Inc. & NCT00900809 \\
\hline 15 & $\begin{array}{l}\text { Hematological } \\
\text { malignancies }\end{array}$ & $\begin{array}{l}\text { Neukoplast }{ }^{\mathrm{TM}} \text { (NK-92), } 1-5 \times 10^{9} / \mathrm{m}^{2} \\
\text { relapse after autologous HSCT; phase I }\end{array}$ & Recruiting & $\begin{array}{l}\text { University Health Network, } \\
\text { Toronto }\end{array}$ & NCT00990717 \\
\hline 16 & AL, MDS & NK cells and IL-2 before UCBT; phase II & $\begin{array}{l}\text { Terminated (competing } \\
\text { study started) }\end{array}$ & $\begin{array}{l}\text { Masonic Cancer Center, } \\
\text { University of Minnesota }\end{array}$ & NCT00354172 \\
\hline 18 & LY or solid tumors & $\begin{array}{l}\text { Ex vivo-expanded allogeneic NK cells } \\
\text { (MG4101); phase I }\end{array}$ & Completed (03/13) & $\begin{array}{l}\text { Seoul National University } \\
\text { Hospital, Korea }\end{array}$ & NCT01212341 \\
\hline N.A. & $\begin{array}{l}\text { Hematological } \\
\text { malignancies, solid } \\
\text { tumors }\end{array}$ & $\begin{array}{l}\text { Autologous NK cells } 24 \mathrm{~h} \text { after treatment with } \\
\text { bortezomib; IL-2; phase I }\end{array}$ & Recruiting & $\begin{array}{l}\text { National Heart, Lung, and } \\
\text { Blood Institute, MD, USA }\end{array}$ & NCT00720785 \\
\hline
\end{tabular}

AML, acute myeloid leukemia; MRD, minimal residual disease; ALL, acute lymphoblastic leukemia; LY, lymphoma; MY, multiple myeloma; JMML, juvenile myelomonocytic leukemia; NHL, non-Hodgkin lymphoma; CY, cyclophosphamide; FLU, fludarabine; UCBT, umbilical cord blood transplantation; RIC, reduced intensity conditioning; MRD, matched related donor;

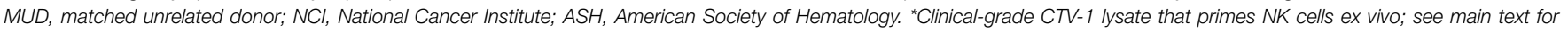
further details. N.A. , not available. www.clinicaltrials. gov website, last accessed March 2015.

Haploidentical, KIR-ligand-mismatched NK cells have been safely infused in elderly patients with high-risk AML, with some evidence of clinical benefit, especially for patients treated in CR or for those with molecular disease relapse (75). Approximately, $40 \%$ of the screened patients had a KIR-ligand-mismatched donor, suggesting that this strategy may be applicable to a significant proportion of patients with AML. Another study attempted to exploit KIR-ligand-mismatched NK cells from haploidentical family donors in patients with relapsed MM (74). The apheresis products were TCD and then cultured with IL-2, either overnight or during incubation with anti-CD3 beads. Patients received melphalan and fludarabine as conditioning regimen. After NKcell infusion, IL-15 levels increased. The response rate (RR) was $50 \%$, with no patient developing GVHD. However, donor chimerism was eventually lost in conjunction with the appearance of host-anti-donor immune responses. The clinical application of allogeneic NK cells to patients with MM is further encouraged by the observation that most MM cell lines are susceptible to NK attack in vitro, showing no evidence for HLA class I loss (146).

Resting human NK cells can be primed to kill NK-resistant tumor cells by co-incubation with a clinical-grade lysate of the leukemia cell line CTV-1 (CNDO-109). CNDO-109-activated NK cells remain primed, with no requirement for IL-2 treatment, and can be cryopreserved. The safety, outcome and NK chimerism data from an ongoing phase I/II transitional clinical trial of CNDO-109-NK cells have been recently reported (77). This $3 \times 3$ dose-escalation phase 1 study was opened in 2013 for patients with high-risk AML in first CR and with no conventional treatment options available. Patients received preparative chemotherapy consisting of cyclophosphamide and fludarabine on study day- 6 to -2 , followed by a single dose of CNDO-109-activated NK cells on day 0. Patients were given different doses of NK cells (cohort $1=3 \times 10^{5}$, cohort $2=1 \times 10^{6}$, and cohort $3=$ up to $3 \times 10^{6}$ cells $/ \mathrm{kg}$ ). CNDO-109-NK cells were manufactured from a single apheresis collection from HLA-haploidentical-related donors. NK cells were isolated with anti-CD56 microbeads and co-incubated overnight with CNDO-109 lysate under GMP conditions (Coronado Biosciences) ${ }^{2}$. Residual T-cell contamination (defined as $<10^{4}$ cells/kg patient body weight) was considered a safety criterion for lot release. Seven eligible patients were enrolled. No infusion-related toxicities or adverse events directly attributed to NK therapy were observed, including GVHD. Patients experienced transient myelosuppression lasting approximately 2 weeks. Three patients relapsed early post-treatment (average time to relapse from CR1 being 104 days). In five of seven evaluable patients, persistence of activated donor NK cells was observed from day 7 post-infusion to as late as day 56 in one patient. The comparison of donor and patient endogenous NK cells showed a mature activated phenotype of donor NK cells. Two of the three patients evaluated had persistence of low levels of activated autologous NK cells ( $10-20 \%$ of circulating NK cells), exceeding the numbers circulating pre-treatment. This observation may indicate that NK-cell therapy induces endogenous NK activation and enhances innate immunity to AML in the absence of exogenous cytokine administration. When the study was published in abstract form, four of the seven patients enrolled were relapse-free.

Natural killer cells have also been administered pre-emptively to patients with high-risk cancer, after TCD haploidentical HSCT (73). Sixteen patients were treated in a prospective phase II study with purified NK cells on day 3, 40, and 100 after HSCT. The median dose of NK cells was $12.1 \times 10^{6} / \mathrm{kg}$. With a median follow-up of approximately 6 years, 4 out of 16 patients were alive. The four patients who developed acute GVHD had received $>0.5 \times 10^{5} / \mathrm{kg}$ contaminating T cells. Compared with a historical cohort of patients treated with haploidentical HSCT without NK donor lymphocyte infusions (DLIs), NK cells apparently exerted no effect on disease relapse.

\footnotetext{
${ }^{2}$ http://www.coronadobiosciences.com/research-development/cndo-109.cfm
} 


\section{Trials in Children and Young Adolescents}

A landmark study from St. Jude Children's Hospital (NKAML) has shown the safety, feasibility, and engraftment potential of haploidentical NK cells for children with favorable and intermediaterisk AML (59). Patients received a mild conditioning regimen, consisting of cyclophosphamide $(60 \mathrm{mg} / \mathrm{kg}$ on day-7) and fludarabine $\left(25 \mathrm{mg} / \mathrm{m}^{2} /\right.$ day from day- 6 to -2$)$, followed by KIRHLA-mismatched NK cells (median number of cells infused $\left.29 \times 10^{6} / \mathrm{kg}\right)$ and six doses of IL-2 $\left(1 \times 10^{6} \mathrm{U} / \mathrm{m}^{2}\right)$. Donor PBMCs obtained by leukapheresis were depleted of $\mathrm{CD}^{+} \mathrm{T}$ cells and then enriched for $\mathrm{CD}^{2} 6^{+}$cells. The manipulated product contained a very low number of contaminating $B$ cells and $T$ cells. The resulting NK population was infused fresh, without any incubation with IL-2. All patients were in CR, as shown by minimal residual disease status. NK infusions were well tolerated, with no GVHD observed. NK-cell engraftment was transient in all patients, with a median peak NK-cell chimerism of 7\%. One patient had prolonged NK engraftment with $2 \%$ of donor NK cells being detected at day 189 , in association with delayed neutrophil and platelet engraftment. With a median follow-up of approximately 32 months, all patients remained in remission. The 2-year EFS estimate was $100 \%$.

The therapeutic potential of NK cells has also been tested in young adolescents. A two-step T-cell depletion strategy with a final CD56 enrichment step was pursued to isolate NK cells from steady-state leukapheresis collections (147). Purified NK cells were expanded for 2 weeks in X-VIVO 10 medium containing $10 \%$ human $\mathrm{AB}$ serum and 1,000 $\mathrm{U} / \mathrm{ml} \mathrm{IL}-2$. This procedure resulted in a median $95 \%$ NK-cell purity, $99 \%$ viability, and enhanced cytotoxicity against the K562 line as well as primary leukemic blasts obtained from patients. T-cell contamination was negligible $(<0.1 \%)$. Three children with multiply relapsed ALL or AML were treated with IL-2-stimulated NK cells after haploidentical HSCT. Directed KIR mismatches in the GVL direction were present in all three cases. Remission was achieved in all cases, although patients ultimately died of infectious complications or disease relapse. Another study in children and young adolescents with ultra-high-risk solid tumors has shown that donor-derived NK cells activated with IL-15 and 41BBL can be safely administered after HLA-matched TCD HSCT (148). NK cells displayed potent killing capacity. However, five of nine transplant recipients developed acute GVHD, with grade III GVHD being observed in three patients. The unexpected occurrence of GVHD in this report may be attributed to timing of NK-cell infusion, lack of posttransplantation immune suppression or activation of NK cells that were expanded on IL-15-secreting feeder cells (149). The observation that GVHD developed in all four patients given unrelated donor transplants compared with one of five patients given related donor transplants points to a T-cell-driven mechanism, mediated by minor antigens and accentuated by the infused NK cells.

\section{In vivo Targeting of NK Cells with Antibodies}

IPH2101 is a first-in-class, non-depleting human $\operatorname{IgG}_{4} \mathrm{mAb}$ directed against inhibitory KIRs, and functions by blocking inhibitory KIR-ligand interactions, leading to restored or augmented NK-cell function against tumor cells. A phase I trial of IPH2101 (\#NCT00552396) was conducted in 32 patients with relapsed/refractory MM (150). IPH2101 was given intravenously every 28 days in sevn dose-escalated cohorts $(0.0003-3 \mathrm{mg} / \mathrm{kg})$ for up to four cycles. This study identified doses of IPH2101, which conferred KIR2D occupancy in vivo, with no concomitant dose-limiting toxicity or identification of a maximally tolerated dose (MTD). With one exception, adverse events were mild and transient and mainly consisted of self-limited infusion reactions. Although IPH2101 enhanced ex vivo patient-derived NK-cell cytotoxicity against MM, no objective responses were observed. Another phase I study of escalating doses of IPH2101 in 23 elderly patients with AML in first CR showed a correlation between IPH2101 exposure and KIR occupancy (151). Adverse events were mild and transient, consisting mainly of infusion syndrome and erythema. The study drug did not affect the numbers and distribution of lymphocyte subsets and NK cell receptor expression. At the highest dose levels, TNF- $\alpha$ and MIP-1 $\beta$ serum concentrations, as well as CD69 expression on NK cells, transiently increased. Overall and relapse-free survival compared favorably to reports in other patient populations with similar characteristics (151).

An immunization study of transgenic mice bearing human immunoglobulin loci with different combinations of KIR2DLs has recently led to the identification of the 1-7F9 mAb, based on binding to soluble, recombinant KIR2DL1, -2 , and -3 by ELISA (152). The 1-7F9 antibodies bind to human NK cells, $\gamma \delta^{+} \mathrm{T}$ cells, and $\mathrm{CD}^{+} \mathrm{T}$ cells, consistent with KIR expression patterns. Using in vitro assays, 1-7F9 blocked the binding of HLA class I to inhibitory KIR2DLs, augmenting NK cell-mediated killing of HLA-C-expressing targets. 1-7F9 also enhanced the cytotoxicity of NK cells from an HLA-C-matched donor against AML blasts. Pre-treatment with 1-7F9 of patient-derived NK cells translated into a two- to threefold increase in cytotoxicity against autologous AML cells. Finally, studies in NOD-SCID mice showed that 1-7F9 potentiates NK-mediated killing and promotes mice survival compared with co-infusions of NK cells and AML blasts alone (152).

\section{Bi-Specific and Tri-Specific Antibodies}

A novel class of therapeutics uses either all or part of the antibody structure to deliver enhanced effector activity to the tumor site. The fusion of two (bi-specific) or three (tri-specific) portions of the fragment of antigen-binding (Fab) region of a traditional antibody yields reagents with high level of antigen specificity and cross-links tumor antigens with potent immune effectors. Bi-specific killer engagers (BiKEs) are constructed with a singlechain Fv against CD16 and a single-chain Fv against a tumorassociated antigen. The mechanisms by which BiKEs and TriKEs potentiate NK effector functions include intracellular calcium mobilization through direct CD16 signaling (153). Co-culture of reagent-treated resting NK cells with Raji targets also translates into increased NK-cell degranulation, target cell death, and NK production of IFN- $\gamma$, TNF- $\alpha$, GM-CSF, IL- 8 , MIP- $1 \alpha$, and RANTES.

Fully humanized CD16 $\times 33$ BiKEs have been shown to trigger NK-cell activation in vitro against $\mathrm{CD}_{3}{ }^{+}$AML cell lines and primary refractory $\mathrm{CD}_{3}{ }^{+}$AML targets (154). Combination treatment with BiKEs and ADAM17 inhibitor to prevent CD16 shedding further enhanced NK-cell function. BiKEs were also effective at activating NK cells from recipients of double 
UCB transplantation. BiKEs enhance degranulation and cytokine production by NK cells derived from patients with myelodysplastic syndromes and cultured with $\mathrm{CD} 33^{+}$AML cell lines, irrespective of disease stage and age stratum (155). A potential drawback of this approach is the relatively short halflife of the antibody constructs, with limited trafficking to the tumor site.

\section{Other Approaches to Target NK Cells In vivo}

A first in-human trial of Escherichia coli-produced rhIL-15 has been recently published (156). The primary objectives of this single-institution, open-label, non-randomized $3+3$ design, phase I dose-escalation study were to assess safety, dose-limiting toxicity, and MTD of rhIL-15 given as intravenous bolus at $3.0,1.0$, and $0.3 \mu \mathrm{g} / \mathrm{kg} /$ day for 12 consecutive days to patients with metastatic malignant melanoma or renal cancer. Reductions in the number of lymphocyte subsets were evident within 20 min of the infusion of IL-15, with the most dramatic decline being observed with NK cells, $\gamma \delta^{+} \mathrm{T}$ cells and $\mathrm{CD} 8^{+}$memory $\mathrm{T}$ cells. The acute efflux of $\mathrm{CD}^{+}$cells from the circulation was most pronounced for transitional and effector memory subsets. An influx of NK cells to the blood was detected by $4 \mathrm{~h}$, followed by a normalization of cell counts by $2-3$ days. The initial influx of cells mainly resulted from redistribution, because no evidence of proliferation was observed until $48 \mathrm{~h}$. $\mathrm{CD}^{+}$cells showed evidence of activation, including proliferation and increased expression of CD38 and HLA-DR. Doselimiting toxicities in patients receiving 3.0 and $1.0 \mu \mathrm{g} / \mathrm{kg} /$ day included grade 3 hypotension, thrombocytopenia, and elevations of ALT and AST, resulting in $0.3 \mu \mathrm{g} / \mathrm{kg}$ per day being determined the MTD. Common cytokine-related adverse events, including fever, rigors, and hypotension occurred much less frequently in patients treated with the $0.3 \mu \mathrm{g} / \mathrm{kg}$ dose level. Cytokines such as IFN- $\gamma$, TNF- $\alpha$, IL- 6 , and IL- 8 increased up to 50 -fold in patient serum after rhIL-15 administration. Overall, there were no clinical responses in this study, with stable disease being recorded as a best response. However, five patients manifested a decrease between 10 and $30 \%$ in their marker lesions, with two of these patients experiencing clearing of lung lesions (156). This study proves that rhIL-15 administration, as an intravenous bolus dose, is associated with clinical toxicities due to marked cytokine secretion. The authors initiated a dose-escalation trial of continuous intravenous infusion of rhIL-15 to patients with metastatic malignancies. Furthermore, the Cancer Immunotherapy Trials Network $\left(\mathrm{CITN}^{3}\right)$ is conducting a phase I doseescalation trial of subcutaneous rhIL-15 administered 5 days per week for 2 weeks.

\section{Current Manufacturing Practices for CIK Cells}

Current protocols to differentiate CIK cells are based on the combination of $1,000 \mathrm{IU} / \mathrm{ml} \mathrm{IFN}-\gamma$ on day 1 of culture followed $24 \mathrm{~h}$ later by $50 \mathrm{ng} / \mathrm{ml} \mathrm{OKT3}$ and $300 \mathrm{IU} / \mathrm{ml} \mathrm{IL-2} \mathrm{(157).} \mathrm{After}$ 21-28 days, $\mathrm{CD}^{+}{ }^{+} \mathrm{CD} 56^{+}$cells, derived from $\mathrm{CD} 3{ }^{+} \mathrm{CD} 6^{-}$cells, acquire cytotoxicity against various tumor cell targets, including AML, chronic myeloid leukemia, and B-cell and T-cell lymphoma. The expression of CD56 on CIK cells is thought to result primarily from IFN- $\gamma$ priming with subsequent IL-12 production from monocytes. Recently, a GMP-grade protocol (ITG2) that incorporates thymoglobulin $^{\circledR}$ (TG) was used to prepare CIK cells (Figure 2; Table 3) (45). TG is a purified, pasteurized preparation of polyclonal $\gamma$ immunoglobulin raised in rabbits against human thymocytes (45). TG expanded CIK cells more efficiently than the

${ }^{3}$ http://citninfo.org/citn-science/clinical-studies.html

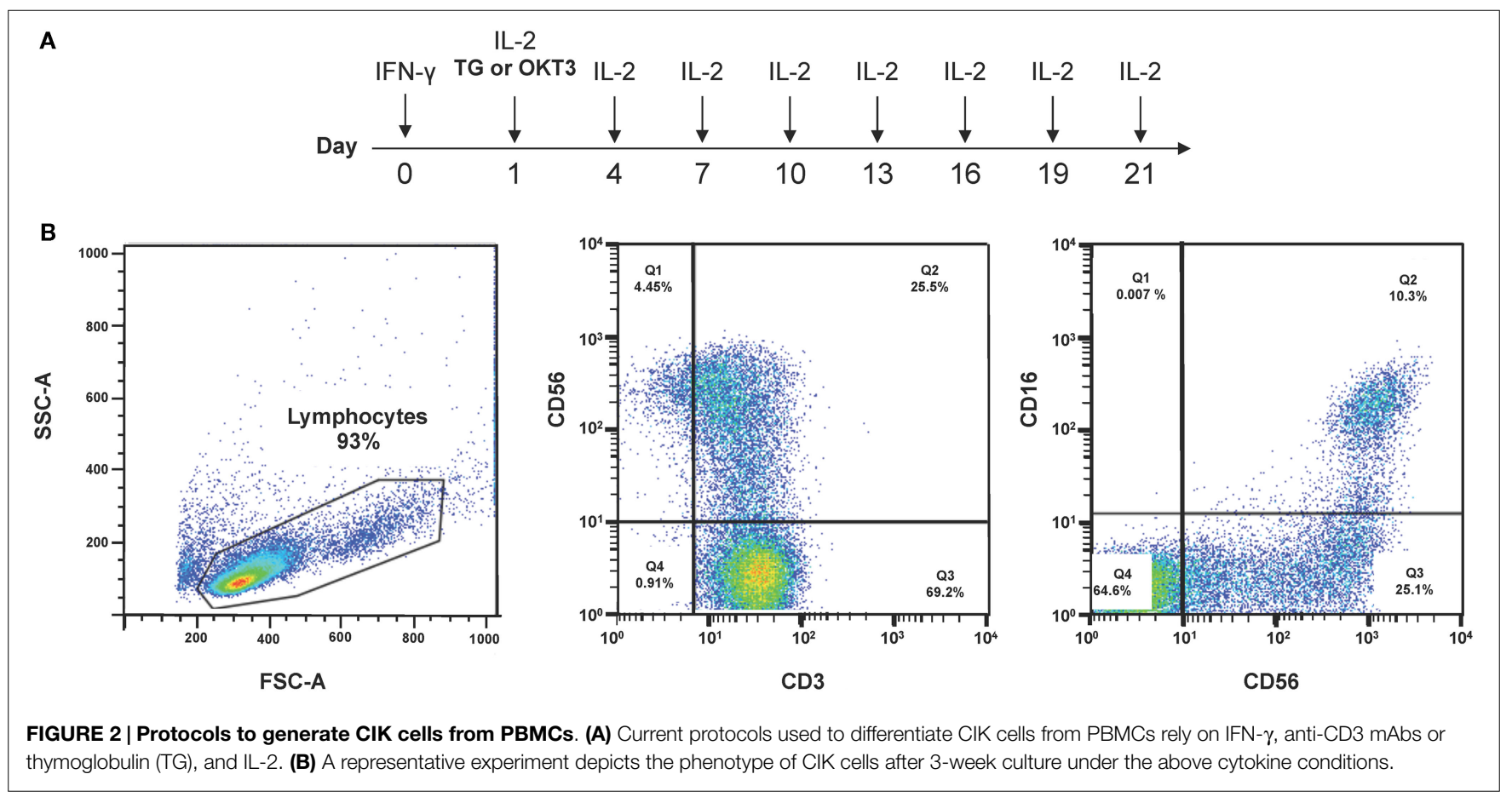


TABLE 3 | Completed and ongoing clinical trials with CIK cells for hematological malignancies are listed.

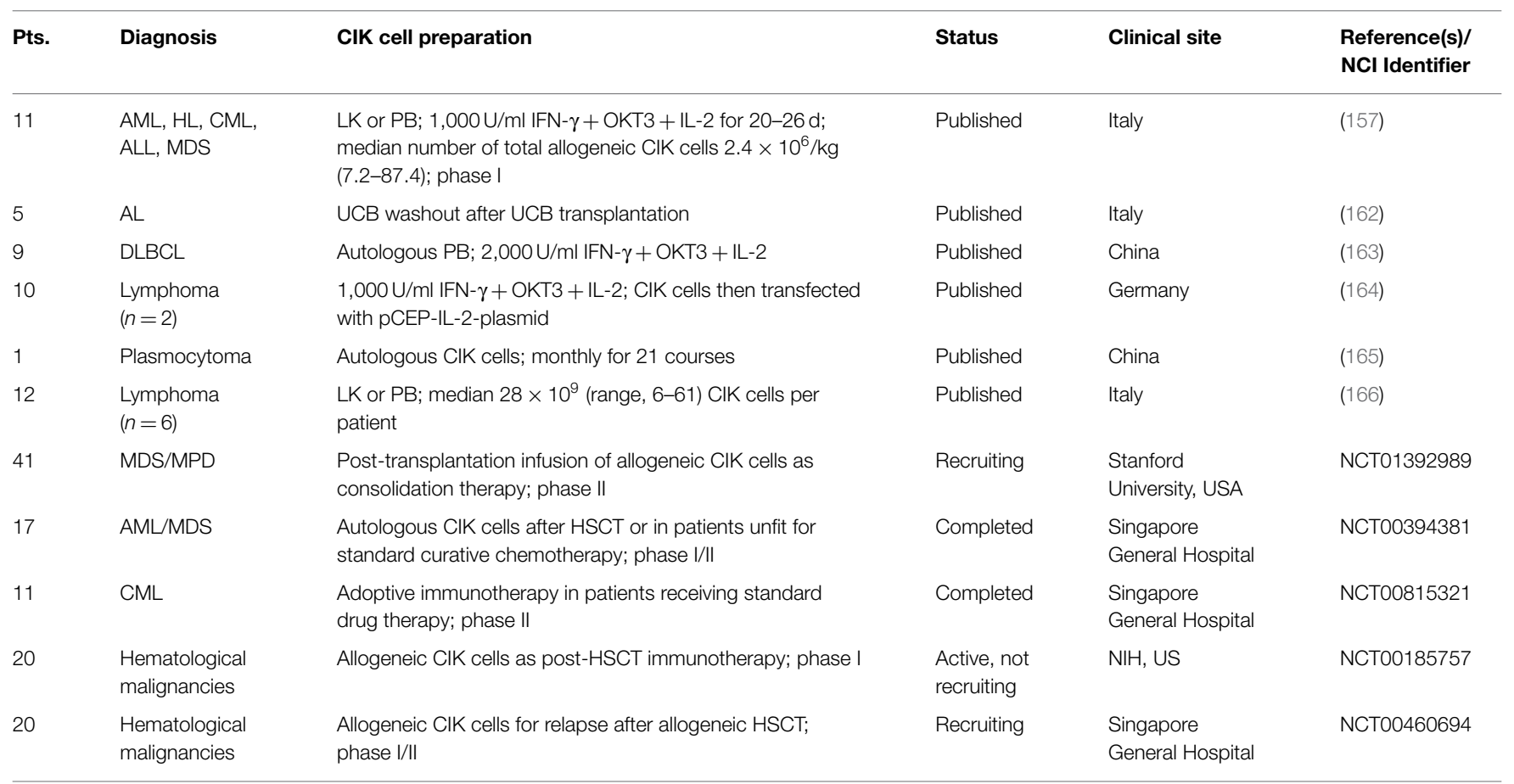

PBMC, peripheral blood mononuclear cells; AL, acute leukemia; DLBCL, diffuse large B-cell lymphoma; LK, leukapheresis; CML, chronic myeloid leukemia; MDS, Myelodysplastic syndromes; MPD, myeloproliferative disorders; d, day; UCB, umbilical cord blood; SCGM, stem cell growth medium; MM, multiple myeloma. www. clinicaltrials. gov website last accessed March 2015.

anti-CD3 $\mathrm{mAb}$ when provided to clinical-grade cultures in combination with IFN- $\gamma$ and IL-2. Higher levels of NKG2D, NKp46triggering receptor, and killer-like immunoglobulin receptors KIR2DL1 and KIR2DL2/DL3 were detected on CIK cells differentiated with TG compared with those obtained with $\alpha \mathrm{CD} 3$ antibodies. CIK cells were capable of lysing tumor cell targets in an MHC-unrestricted manner and released high quantities of bioactive IL-12p40. The use of the ITG2 protocol was not associated with the emergence of Treg cells in vitro, thus reassuring against the infusion of excessive numbers of tumor-suppressive T-cell populations.

The administration of bulk CIK cells is not associated with GVHD in mice, even after sequential infusions (158). The same study also showed that bulk CIK cells are more effective than selected $\mathrm{CD}^{+} 6^{+} \mathrm{CIK}$ cells or CIK cells depleted of potentially alloreactive $\alpha \beta^{+}$CIK cells.

Several investigators have successfully obtained CIK cells from UCB units. The washouts of UCB units may yield approximately $500 \times 10^{6}$ CIK cells after a standardized 21-day expansion culture (159). Compared with PB-derived CIK cells, UCB CIK cells demonstrate lower immunogenicity and higher proliferative capacity and anti-tumor activity in pre-clinical models of cancer (160). Interestingly, UCB-derived CIK cells released higher amounts of IL-2 and IFN- $\gamma$ and expressed higher levels of CCR6 and CCR7, pointing to a better ability to traffic to tumor sites and secondary lymphoid organs. CIK cells differentiated from $\mathrm{PB}$ and UCB also differ in receptor expression and in cytotoxic activity against ALL cells, suggesting that the source of CIK cells may impact on therapeutic efficacy (161).

\section{Clinical Trials with CIK Cells}

An International Registry on CIK Cells (IRCC) has been established with the aim of reporting results from clinical trials centered on adoptively transferred CIK cells. In the first IRCC publication (167), eleven clinical trials with autologous or allogeneic CIK cells were identified, with 426 patients enrolled. Most trials included male patients with hepatocellular carcinoma, gastric cancer, and relapsed lymphoma. A clinical response was reported in 384 patients, who received up to 40 infusions of CIK cells. The total RR was $24 \%$ and a decrease of tumor volume was documented in three patients. DFS rates were significantly higher in patients treated with CIK cells than in a control group without CIK treatment. An update published in 2014 (168) enlists the results obtained in 2,729 patients from 45 phase I/II studies. A total of 1,520 patients with 22 different tumor entities were treated with CIK cells, either alone or in combination with chemotherapy. Allogeneic CIK cells were employed in the majority of the trials (41 out of 45). The number of CIK cells infused varied among the different trials, averaging $7.7 \times 10^{9}$ cells. Data on patient survival were available for 19 out of 45 trials; 15 of these 19 trials were paired, as they also included control patients receiving none or standard therapy alone. Overall, a beneficial effect of CIK cells emerged in patients with hepatocellular carcinoma, renal cell carcinoma, non-small cell lung cancer (NSCLC), colorectal carcinoma, and breast cancer. High numbers of CIK cells at time of infusion were associated with a better prognosis. Quality of life was also improved in four of the five trials for which data were disclosed. Ancillary biological data were provided in 23 studies. The absolute numbers of T cells, as well as serum IFN- $\gamma$, were increased after immunotherapy compared 
with baseline. Some studies also reported a decrease of blood Treg cells after CIK infusions. Immunotherapy was generally well tolerated, with fever occurring in $41 \%$ of cases and headache and fatigue reported in $30 \%$ of cases (168). Mild GVHD was observed in seven of 52 patients treated with allogeneic CIK cells and was responsive to steroid therapy. Based on these findings, the IRCC currently recommends the use of at least $10 \times 10^{9} \mathrm{CIK}$ cells with at least $30 \% \mathrm{CD}^{+}{ }^{+} \mathrm{CD}_{5} 6^{+}$cells per infusion, every $2-4$ weeks, for at least six times. The IRCC website ${ }^{4}$ (last accessed March 2015) lists 1,787 patients treated with CIK cells, mostly for hepatocellular carcinoma, gastric cancer, ovarian cancer, renal cell cancer, MM, and NSCLC.

China has the largest population of patients with malignant tumors and is the country where most clinical trials with CIK cells were conducted (169). Using the VIP database of Chinese scientific and technological journals ${ }^{5}, 24$ articles were selected. Information on the total number of CIK cells used was available in 16 studies and ranged from $6 \times 10^{6}$ to $1.5 \times 10^{10}$ in one single treatment course. As far as hematological malignancies are concerned, 1 study specifically dealt with non-Hodgkin's disease (12 patients) and 4 studies with AML (51 patients). Only 14 out of 24 studies contained details about clinical outcome. Of the reported 563 patients, 40 had a CR, 126 had a partial response, 125 had a minimal response, 135 had stable disease, and 58 had progressive disease. The remaining 76 patients did not reach an objective response. The overall RR was $51.7 \%$ (291/563) (169). Information on patient outcome was provided in 10 studies. Four studies reported a 1 -year OS rate of $72.5 \%$, six studies reported 2-year OS rate of $66.3 \%$, one study reported 3 -year overall RR of $75.5 \%$, and two studies reported 5-year OS rate of $38.2 \%$.

A phase I study of allogeneic CIK cells has been conducted in 11 patients with hematological malignancies relapsing after allogeneic HSCT (157). Six patients had received other salvage treatments before CIK administration, including DLIs, without significant clinical response. The median number of CIK cells infused was $12.4 \times 10^{6} / \mathrm{kg}$, with no infusion-related toxicities recorded. Acute GVHD occurred in four patients 30 days after the last CIK infusion, and progressed into extensive chronic GVHD in two cases. Disease progression and death were observed in six patients. One patient had stable disease, one experienced hematologic improvement, and three obtained complete responses. The same authors differentiated CIK cells from UCB samples and administered them to five patients relapsed after UCB transplantation (162). In three patients, chemotherapy had been given before CIK administration to reduce disease burden. Infusions of a median of $1.5 \times 10^{6} / \mathrm{kg}$ CIK cells were provided early after leukemia relapse. Some clinical response was observed in one patient who also developed acute intestinal GVHD. The remaining four patients experienced disease progression and died. GVHD was managed with steroids and mesenchymal stromal cells but the patient ultimately succumbed to leukemia relapse (162).

In another study (170), CIK cells were generated for 24 patients with advanced-stage hematological malignancies, mostly from

\footnotetext{
${ }^{4}$ http://www.cik-info.org/index.php?kat=tableclinicaltrials

${ }^{5}$ http://oldweb.cqvip.com
}

allogeneic donors, either under steady-state conditions or after stem cell mobilization. Overall, 55 infusions were given to 16 patients at doses ranging from 10 to $200 \times 10^{6} \mathrm{CD}^{+}$cells $/ \mathrm{kg}$. Notably, the proportion of the $\mathrm{CD}^{+}{ }^{+} \mathrm{CD} 56^{+}$subset was higher in CIK cultures derived from patients than in those differentiated from healthy donors. The median expansion of $\mathrm{CD}^{+}$ $\mathrm{T}$ cells and $\mathrm{CD}^{+}{ }^{+} \mathrm{CD}_{56}{ }^{+}$NK-like T-cells was 9.33-fold and 27.77-fold, respectively. Responses attributable to CIK infusions were documented in five patients, including two with ALL, two with Hodgkin disease, and one with AML. In five patients, the response to CIK cells could not be assessed as salvage chemotherapy or dasatinib was concomitantly administered. Acute GVHD occurred in three patients and was manageable. For three of the six patients failing to respond, leukemia cells were available for in vitro killing assays, which showed only modest cytotoxicity of donor CIK cells against tumor targets. Overall, this study in advanced-stage hematological malignancies suggests that CIK administration may translate into some clinical efficacy with a modest toxicity and low incidence and severity of GVHD.

Finally, autologous immune effector cells generated by TG, IFN- $\gamma$, and IL-2 (ITG2) can be safely administered to patients with advanced and/or refractory solid tumors (Figure 2) (171). After $2-3$ weeks in culture, a median of $4.65 \times 10^{6}$ immune effectors $/ \mathrm{kg}$ of recipient's body weight was infused intravenously without observing any toxicity. One patient with advanced melanoma died because of disease progression before the infusion of CIK cells. The target dose of at least $2.5 \times 10^{6} \mathrm{CIK}$ cells $/ \mathrm{kg}$ of recipient's body weight was reached in four out of five evaluable patients. The median survival was 4.5 months (range 1-13) from the first infusion of CIK cells (171).

\section{Closing Remarks}

Although the field of NK cell and CIK cell-based immunotherapy is rapidly advancing, some pre-clinical and clinical issues need to be clarified before this immunotherapy approach is widely offered to patients with hematological malignancies and solid tumors (172).

Cell therapy products enriched for NK cells using CD3 depletion and CD56 selection contain variable percentages of monocytes. It is now established that both monocytes and monocyte-derived DCs can support NK-cell proliferation and function (173). This implies that different NK-cell manufacturing protocols may affect the cellular composition of the final products and impact on NK-cell function. Also, the optimal number of NK cells to be infused remains to be determined. Patients reportedly tolerate target doses of $2 \times 10^{7} \mathrm{NK}$ cells/kg without any serious side effect (78). This number of NK cells can be routinely obtained from a 1-day large-volume leukapheresis. However, it is possible that higher doses and/or multiple infusions of $\mathrm{NK}$ cells may be required for optimal clinical efficacy. Whether NK cells may exert their beneficial effects pre-emptively in patients with disease remission, or rather in the context of HSCT warrants particular attention (73). In this respect, KIR ligand mismatch is expected to mediate a more powerful effect in T-cell-depleted HSCT, since alloreactive $\mathrm{T}$ cells reportedly blunt NK reactivity 
$(37,174)$. Finally, recent discoveries on NK-mediated allorecognition will guide the choice of the optimal NK-cell donor in order to maximally exploit the anti-tumor effect (33). The isolation of single $\mathrm{KIR}^{+} \mathrm{NK}$ cells under GMP conditions is feasible and yields clinically applicable numbers of alloreactive NK cells (65).

\section{References}

1. Farag SS, Fehniger TA, Ruggeri L, Velardi A, Caligiuri MA. Natural killer cell receptors: new biology and insights into the graft-versus-leukemia effect. Blood (2002) 100:1935-47. doi:10.1182/blood-2002-02-0350

2. Knorr DA, Bachanova V, Verneris MR, Miller JS. Clinical utility of natural killer cells in cancer therapy and transplantation. Semin Immunol (2014) 26:161-72. doi:10.1016/j.smim.2014.02.002

3. Cheng M, Chen Y, Xiao W, Sun R, Tian Z. NK cell-based immunotherapy for malignant diseases. Cell Mol Immunol (2013) 10:230-52. doi:10.1038/cmi. 2013.10

4. Rutella S, Bonanno G, Marone M, De Ritis D, Mariotti A, Voso MT, et al. Identification of a novel subpopulation of human cord blood $\mathrm{CD}^{-} 4^{-} \mathrm{CD} 33^{-} \mathrm{CD}^{-} \mathrm{CD}^{+} 5^{+}$lineage ${ }^{-}$cells capable of lymphoid/NK cell differentiation after in vitro exposure to IL-15. J Immunol (2003) 171:2977-88. doi:10.4049/jimmunol.171.6.2977

5. Colonna M, Samaridis J. Cloning of immunoglobulin-superfamily members associated with HLA-C and HLA-B recognition by human natural killer cells. Science (1995) 268:405-8. doi:10.1126/science.7716543

6. D’Andrea A, Chang C, Franz-Bacon K, McClanahan T, Phillips JH, Lanier LL. Molecular cloning of NKB1. A natural killer cell receptor for HLA-B allotypes. J Immunol (1995) 155:2306-10.

7. Wagtmann N, Biassoni R, Cantoni C, Verdiani S, Malnati MS, Vitale M, et al. Molecular clones of the p58 NK cell receptor reveal immunoglobulinrelated molecules with diversity in both the extra- and intracellular domains. Immunity (1995) 2:439-49. doi:10.1016/1074-7613(95)90025-X

8. Burshtyn DN, Scharenberg AM, Wagtmann N, Rajagopalan S, Berrada K, Yi $\mathrm{T}$, et al. Recruitment of tyrosine phosphatase HCP by the killer cell inhibitor receptor. Immunity (1996) 4:77-85. doi:10.1016/S1074-7613(00)80300-3

9. Burshtyn DN, Yang W, Yi T, Long EO. A novel phosphotyrosine motif with a critical amino acid at position -2 for the $\mathrm{SH} 2$ domain-mediated activation of the tyrosine phosphatase SHP-1. J Biol Chem (1997) 272:13066-72. doi:10. $1074 /$ jbc. 272.20 .13066

10. Campbell KS, Dessing M, Lopez-Botet M, Cella M, Colonna M. Tyrosine phosphorylation of a human killer inhibitory receptor recruits protein tyrosine phosphatase 1C. J Exp Med (1996) 184:93-100. doi:10.1084/jem.184.1.93

11. Fry AM, Lanier LL, Weiss A. Phosphotyrosines in the killer cell inhibitory receptor motif of NKB1 are required for negative signaling and for association with protein tyrosine phosphatase 1C. J Exp Med (1996) 184:295-300. doi:10. 1084/jem.184.1.295

12. Biassoni R, Cantoni C, Falco M, Verdiani S, Bottino C, Vitale M, et al. The human leukocyte antigen (HLA)-C-specific "activatory" or "inhibitory" natural killer cell receptors display highly homologous extracellular domains but differ in their transmembrane and intracytoplasmic portions. J Exp Med (1996) 183:645-50. doi:10.1084/jem.183.2.645

13. Olcese L, Cambiaggi A, Semenzato G, Bottino C, Moretta A, Vivier E. Human killer cell activatory receptors for MHC class I molecules are included in a multimeric complex expressed by natural killer cells. J Immunol (1997) 158:5083-6.

14. Campbell KS, Cella M, Carretero M, Lopez-Botet M, Colonna $M$. Signaling through human killer cell activating receptors triggers tyrosine phosphorylation of an associated protein complex. Eur $J$ Immunol (1998) 28:599-609. doi:10.1002/(SICI)1521-4141(199802)28:02<599:: AID-IMMU599>3.3.CO;2-6

15. Zhang J, Basher F, Wu JD. NKG2D ligands in tumor immunity: two sides of a coin. Front Immunol (2015) 6:97. doi:10.3389/fimmu.2015.00097

16. Li P, Morris DL, Willcox BE, Steinle A, Spies T, Strong RK. Complex structure of the activating immunoreceptor NKG2D and its MHC class I-like ligand MICA. Nat Immunol (2001) 2:443-51. doi:10.1038/87757
Current clinical evidence also points to CIK cells as a potentially useful immunotherapy approach for cancer patients. Similar to other forms of immunotherapy, the infusion of CIK cells may be more efficacious at disease stages where the tumor burden is relatively low or in an adjuvant setting, rather than for advanced disease (175).

17. Cosman D, Mullberg J, Sutherland CL, Chin W, Armitage R, Fanslow W, et al ULBPs, novel MHC class I-related molecules, bind to CMV glycoprotein UL16 and stimulate NK cytotoxicity through the NKG2D receptor. Immunity (2001) 14:123-33. doi:10.1016/S1074-7613(01)00095-4

18. Vitale M, Bottino C, Sivori S, Sanseverino L, Castriconi R, Marcenaro E, et al. NKp44, a novel triggering surface molecule specifically expressed by activated natural killer cells, is involved in non-major histocompatibility complexrestricted tumor cell lysis. J Exp Med (1998) 187:2065-72. doi:10.1084/jem. 187.12.2065

19. Pende D, Parolini S, Pessino A, Sivori S, Augugliaro R, Morelli L, et al. Identification and molecular characterization of $\mathrm{NKp} 30$, a novel triggering receptor involved in natural cytotoxicity mediated by human natural killer cells. J Exp Med (1999) 190:1505-16. doi:10.1084/jem.190.10.1505

20. Pende D, Cantoni C, Rivera P, Vitale M, Castriconi R, Marcenaro S, et al Role of NKG2D in tumor cell lysis mediated by human NK cells: cooperation with natural cytotoxicity receptors and capability of recognizing tumors of nonepithelial origin. Eur J Immunol (2001) 31:1076-86. doi:10.1002/ 1521-4141(200104)31:4<1076::AID-IMMU1076>3.0.CO;2-Y

21. Venstrom JM, Dupont B, Hsu KC, Pittari G, Gooley TA, Chewning JH, et al Donor activating KIR2DS1 in leukemia. N Engl J Med (2014) 371:2042. doi:10. 1056/NEJMc1411443

22. Venstrom JM, Pittari G, Gooley TA, Chewning JH, Spellman S, Haagenson M, et al. HLA-C-dependent prevention of leukemia relapse by donor activating KIR2DS1. N Engl J Med (2012) 367:805-16. doi:10.1056/NEJMoa1200503

23. Ruggeri L, Capanni M, Urbani E, Perruccio K, Shlomchik WD, Tosti A, et al. Effectiveness of donor natural killer cell alloreactivity in mismatched hematopoietic transplants. Science (2002) 295:2097-100. doi:10.1126/science. 1068440

24. Aversa F, Tabilio A, Velardi A, Cunningham I, Terenzi A, Falzetti F, et al. Treatment of high-risk acute leukemia with T-cell-depleted stem cells from related donors with one fully mismatched HLA haplotype. N Engl J Med (1998) 339:1186-93. doi:10.1056/NEJM199810223391702

25. Biassoni R, Falco M, Cambiaggi A, Costa P, Verdiani S, Pende D, et al. Amino acid substitutions can influence the natural killer (NK)-mediated recognition of HLA-C molecules. Role of serine-77 and lysine- 80 in the target cell protection from lysis mediated by "group 2" or "group 1" NK clones. J Exp Med (1995) 182:605-9. doi:10.1084/jem.182.2.605

26. Gumperz JE, Litwin V, Phillips JH, Lanier LL, Parham P. The Bw4 public epitope of HLA-B molecules confers reactivity with natural killer cell clones that express NKB1, a putative HLA receptor. J Exp Med (1995) 181:1133-44. doi:10.1084/jem.181.3.1133

27. Litwin V, Gumperz J, Parham P, Phillips JH, Lanier LL. NKB1: a natural killer cell receptor involved in the recognition of polymorphic HLA-B molecules. $J$ Exp Med (1994) 180:537-43. doi:10.1084/jem.180.2.537

28. Wagtmann N, Rajagopalan S, Winter CC, Peruzzi M, Long EO. Killer cell inhibitory receptors specific for HLA-C and HLA-B identified by direct binding and by functional transfer. Immunity (1995) 3:801-9. doi:10.1016/ 1074-7613(95)90069-1

29. Winter CC, Long EO. A single amino acid in the p58 killer cell inhibitory receptor controls the ability of natural killer cells to discriminate between the two groups of HLA-C allotypes. J Immunol (1997) 158:4026-8.

30. Ljunggren HG, Karre K. In search of the 'missing self': MHC molecules and NK cell recognition. Immunol Today (1990) 11:237-44. doi:10.1016/ 0167-5699(90)90097-S

31. Cooley S, Weisdorf DJ, Guethlein LA, Klein JP, Wang T, Marsh SG, et al. Donor killer cell Ig-like receptor B haplotypes, recipient HLA-C1, and HLA$\mathrm{C}$ mismatch enhance the clinical benefit of unrelated transplantation for acute myelogenous leukemia. J Immunol (2014) 192:4592-600. doi:10.4049/ jimmunol.1302517 
32. Oevermann L, Michaelis SU, Mezger M, Lang P, Toporski J, Bertaina A, et al. KIR B haplotype donors confer a reduced risk for relapse after haploidentical transplantation in children with ALL. Blood (2014) 124:2744-7. doi:10.1182/ blood-2014-03-565069

33. Cooley S, Weisdorf DJ, Guethlein LA, Klein JP, Wang T, Le CT, et al. Donor selection for natural killer cell receptor genes leads to superior survival after unrelated transplantation for acute myelogenous leukemia. Blood (2010) 116:2411-9. doi:10.1182/blood-2010-05-283051

34. Benjamin JE, Gill S, Negrin RS. Biology and clinical effects of natural killer cells in allogeneic transplantation. Curr Opin Oncol (2010) 22:130-7. doi:10. 1097/CCO.0b013e328335a559

35. Pittari G, Fregni G, Roguet L, Garcia A, Vataire AL, Wittnebel S, et al. Early evaluation of natural killer activity in post-transplant acute myeloid leukemia patients. Bone Marrow Transplant (2010) 45:862-71. doi:10.1038/ bmt.2009.265

36. Schumm M, Lang P, Bethge W, Faul C, Feuchtinger T, Pfeiffer M, et al. Depletion of T-cell receptor $\alpha \beta$ and CD19 positive cells from apheresis products with the Clini-MACS device. Cytotherapy (2013) 15:1253-8. doi:10.1016/j.jcyt. 2013.05.014

37. Rutella S, Filippini P, Bertaina V, Li Pira G, Altomare L, Ceccarelli S, et al. Mobilization of healthy donors with plerixafor affects the cellular composition of T-cell receptor (TCR)- $\alpha \beta / C D 19$-depleted haploidentical stem cell grafts. J Transl Med (2014) 12:240. doi:10.1186/s12967-014-0240-z

38. Braud VM, Allan DS, O'Callaghan CA, Soderstrom K, D'Andrea A, Ogg GS, et al. HLA-E binds to natural killer cell receptors CD94/NKG2A, B and C. Nature (1998) 391:795-9. doi:10.1038/35869

39. Llano M, Lee N, Navarro F, Garcia P, Albar JP, Geraghty DE, et al. HLA-E-bound peptides influence recognition by inhibitory and triggering CD94/NKG2 receptors: preferential response to an HLA-G-derived nonamer. Eur J Immunol (1998) 28:2854-63. doi:10.1002/(SICI)1521-4141(199809)28: 09<2854::AID-IMMU2854>3.0.CO;2-W

40. Lotze MT, Grimm EA, Mazumder A, Strausser JL, Rosenberg SA. Lysis of fresh and cultured autologous tumor by human lymphocytes cultured in T-cell growth factor. Cancer Res (1981) 41:4420-5.

41. Yron I, Wood TA Jr, Spiess PJ, Rosenberg SA. In vitro growth of murine T cells. V. The isolation and growth of lymphoid cells infiltrating syngeneic solid tumors. J Immunol (1980) 125:238-45.

42. Grimm EA, Mazumder A, Zhang HZ, Rosenberg SA. Lymphokine-activated killer cell phenomenon. Lysis of natural killer-resistant fresh solid tumor cells by interleukin 2-activated autologous human peripheral blood lymphocytes. J Exp Med (1982) 155:1823-41. doi:10.1084/jem.155.6.1823

43. Phillips JH, Gemlo BT, Myers WW, Rayner AA, Lanier LL. In vivo and in vitro activation of natural killer cells in advanced cancer patients undergoing combined recombinant interleukin-2 and LAK cell therapy. J Clin Oncol (1987) 5:1933-41.

44. Phillips JH, Lanier LL. Dissection of the lymphokine-activated killer phenomenon. Relative contribution of peripheral blood natural killer cells and $\mathrm{T}$ lymphocytes to cytolysis. J Exp Med (1986) 164:814-25. doi:10.1084/jem.164. 3.814

45. Bonanno G, Iudicone P, Mariotti A, Procoli A, Pandolfi A, Fioravanti D, et al. Thymoglobulin, interferon- $\gamma$ and interleukin-2 efficiently expand cytokineinduced killer (CIK) cells in clinical-grade cultures. J Transl Med (2010) 8:129. doi:10.1186/1479-5876-8-129

46. Jiang J, Wu C, Lu B. Cytokine-induced killer cells promote antitumor immunity. J Transl Med (2013) 11:83. doi:10.1186/1479-5876-11-83

47. Schmidt-Wolf IG, Negrin RS, Kiem HP, Blume KG, Weissman IL. Use of a SCID mouse/human lymphoma model to evaluate cytokine-induced killer cells with potent antitumor cell activity. J Exp Med (1991) 174:139-49. doi:10. 1084/jem.174.1.139

48. Kim HM, Lim J, Kang JS, Park SK, Lee K, Kim JY, et al. Inhibition of human cervical carcinoma growth by cytokine-induced killer cells in nude mouse xenograft model. Int Immunopharmacol (2009) 9:375-80. doi:10.1016/ j.intimp.2008.12.001

49. Sweeney TJ, Mailander V, Tucker AA, Olomu AB, Zhang W, Cao Y, et al. Visualizing the kinetics of tumor-cell clearance in living animals. Proc Natl Acad Sci U S A (1999) 96:12044-9. doi:10.1073/pnas.96.21.12044

50. Verneris MR, Ito M, Baker J, Arshi A, Negrin RS, Shizuru JA. Engineering hematopoietic grafts: purified allogeneic hematopoietic stem cells plus expanded CD8+ NK-T cells in the treatment of lymphoma. Biol Blood Marrow Transplant (2001) 7:532-42. doi:10.1016/S1083-8791(01)70014-6

51. Edinger M, Cao YA, Verneris MR, Bachmann $\mathrm{MH}$, Contag $\mathrm{CH}$, Negrin RS. Revealing lymphoma growth and the efficacy of immune cell therapies using in vivo bioluminescence imaging. Blood (2003) 101:640-8. doi:10.1182/ blood-2002-06-1751

52. Koepsell SA, Miller JS, McKenna DH Jr. Natural killer cells: a review of manufacturing and clinical utility. Transfusion (2013) 53:404-10. doi:10.1111/ j.1537-2995.2012.03724.x

53. Chouaib S, Pittari G, Nanbakhsh A, El Ayoubi H, Amsellem S, Bourhis JH, et al. Improving the outcome of leukemia by natural killer cell-based immunotherapeutic strategies. Front Immunol (2014) 5:95. doi:10.3389/ fimmu.2014.00095

54. Miller JS, Prosper F, McCullar V. Natural killer (NK) cells are functionally abnormal and NK cell progenitors are diminished in granulocyte colonystimulating factor-mobilized peripheral blood progenitor cell collections. Blood (1997) 90:3098-105.

55. Spanholtz J, Preijers F, Tordoir M, Trilsbeek C, Paardekooper J, de Witte T, et al. Clinical-grade generation of active NK cells from cord blood hematopoietic progenitor cells for immunotherapy using a closed-system culture process. PLoS One (2011) 6:e20740. doi:10.1371/journal.pone.0020740

56. Tanaka J, Sugita J, Shiratori S, Shigematu A, Asanuma S, Fujimoto K, et al. Expansion of NK cells from cord blood with antileukemic activity using GMP-compliant substances without feeder cells. Leukemia (2012) 26:1149-52. doi:10.1038/leu.2011.345

57. Miller JS, Soignier Y, Panoskaltsis-Mortari A, McNearney SA, Yun GH, Fautsch SK, et al. Successful adoptive transfer and in vivo expansion of human haploidentical NK cells in patients with cancer. Blood (2005) 105:3051-7. doi:10.1182/blood-2004-07-2974

58. McKenna DH Jr, Sumstad D, Bostrom N, Kadidlo DM, Fautsch S, McNearney $S$, et al. Good manufacturing practices production of natural killer cells for immunotherapy: a six-year single-institution experience. Transfusion (2007) 47:520-8. doi:10.1111/j.1537-2995.2006.01145.x

59. Rubnitz JE, Inaba H, Ribeiro RC, Pounds S, Rooney B, Bell T, et al. NKAML: a pilot study to determine the safety and feasibility of haploidentical natural killer cell transplantation in childhood acute myeloid leukemia. J Clin Oncol (2010) 28:955-9. doi:10.1200/JCO.2009.24.4590

60. Iyengar R, Handgretinger R, Babarin-Dorner A, Leimig T, Otto M, Geiger TL, et al. Purification of human natural killer cells using a clinicalscale immunomagnetic method. Cytotherapy (2003) 5:479-84. doi:10.1080/ 14653240310003558

61. Sutlu T, Stellan B, Gilljam M, Quezada HC, Nahi H, Gahrton G, et al. Clinicalgrade, large-scale, feeder-free expansion of highly active human natural killer cells for adoptive immunotherapy using an automated bioreactor. Cytotherapy (2010) 12:1044-55. doi:10.3109/14653249.2010.504770

62. Luhm J, Brand JM, Koritke P, Hoppner M, Kirchner H, Frohn C. Large-scale generation of natural killer lymphocytes for clinical application. J Hematother Stem Cell Res (2002) 11:651-7. doi:10.1089/15258160260194794

63. Tonn T, Schwabe D, Klingemann HG, Becker S, Esser R, Koehl U, et al. Treatment of patients with advanced cancer with the natural killer cell line NK-92. Cytotherapy (2013) 15:1563-70. doi:10.1016/j.jcyt.2013.06.017

64. Tam YK, Martinson JA, Doligosa K, Klingemann HG. Ex vivo expansion of the highly cytotoxic human natural killer-92 cell-line under current good manufacturing practice conditions for clinical adoptive cellular immunotherapy. Cytotherapy (2003) 5:259-72. doi:10.1080/14653240310001523

65. Siegler U, Meyer-Monard S, Jorger S, Stern M, Tichelli A, Gratwohl A, et al. Good manufacturing practice-compliant cell sorting and large-scale expansion of single KIR-positive alloreactive human natural killer cells for multiple infusions to leukemia patients. Cytotherapy (2010) 12:750-63. doi:10.3109/ 14653241003786155

66. Klingemann HG, Martinson J. Ex vivo expansion of natural killer cells for clinical applications. Cytotherapy (2004) 6:15-22. doi:10.1080/ 14653240310004548

67. Fujisaki H, Kakuda H, Shimasaki N, Imai C, Ma J, Lockey T, et al. Expansion of highly cytotoxic human natural killer cells for cancer cell therapy. Cancer Res (2009) 69:4010-7. doi:10.1158/0008-5472.CAN-08-3712

68. Parkhurst MR, Riley JP, Dudley ME, Rosenberg SA. Adoptive transfer of autologous natural killer cells leads to high levels of circulating natural killer cells 
but does not mediate tumor regression. Clin Cancer Res (2011) 17:6287-97. doi:10.1158/1078-0432.CCR-11-1347

69. Berg M, Lundqvist A, McCoy P Jr, Samsel L, Fan Y, Tawab A, et al. Clinical-grade ex vivo-expanded human natural killer cells up-regulate activating receptors and death receptor ligands and have enhanced cytolytic activity against tumor cells. Cytotherapy (2009) 11:341-55. doi:10.1080/ 14653240902807034

70. Lang P, Pfeiffer M, Handgretinger R, Schumm M, Demirdelen B, Stanojevic $\mathrm{S}$, et al. Clinical scale isolation of T cell-depleted CD56+ donor lymphocytes in children. Bone Marrow Transplant (2002) 29:497-502. doi:10.1038/sj.bmt. 1703406

71. Alici E, Sutlu T, Bjorkstrand B, Gilljam M, Stellan B, Nahi H, et al. Autologous antitumor activity by NK cells expanded from myeloma patients using GMP-compliant components. Blood (2008) 111:3155-62. doi:10.1182/ blood-2007-09-110312

72. Yoon SR, Lee YS, Yang SH, Ahn KH, Lee JH, Lee JH, et al. Generation of donor natural killer cells from CD34+ progenitor cells and subsequent infusion after HLA-mismatched allogeneic hematopoietic cell transplantation: a feasibility study. Bone Marrow Transplant (2010) 45:1038-46. doi:10.1038/ bmt.2009.304

73. Stern M, Passweg JR, Meyer-Monard S, Esser R, Tonn T, Soerensen J, et al. Preemptive immunotherapy with purified natural killer cells after haploidentical SCT: a prospective phase II study in two centers. Bone Marrow Transplant (2013) 48:433-8. doi:10.1038/bmt.2012.162

74. Shi J, Tricot G, Szmania S, Rosen N, Garg TK, Malaviarachchi PA, et al. Infusion of haplo-identical killer immunoglobulin-like receptor ligand mismatched NK cells for relapsed myeloma in the setting of autologous stem cell transplantation. Br J Haematol (2008) 143:641-53. doi:10.1111/j.1365-2141. 2008.07340.x

75. Curti A, Ruggeri L, D’Addio A, Bontadini A, Dan E, Motta MR, et al. Successful transfer of alloreactive haploidentical KIR ligand-mismatched natural killer cells after infusion in elderly high risk acute myeloid leukemia patients. Blood (2011) 118:3273-9. doi:10.1182/blood-2011-01-329508

76. Bachanova V, Burns LJ, McKenna DH, Curtsinger J, Panoskaltsis-Mortari A, Lindgren BR, et al. Allogeneic natural killer cells for refractory lymphoma. Cancer Immunol Immunother (2010) 59:1739-44. doi:10.1007/ s00262-010-0896-z

77. Fehniger TA, Stuart RK, Cooley SA, Miller JS, Curtsinger J, Hillman TM, et al. Preliminary results of a phase $1 / 2$ clinical trial of CNDO-109-activated allogeneic natural killer cells in high risk acute myelogenous leukemia patients in first complete remission. Hematology Am Soc Hematol Educ Program (2014) 124:2320.

78. Klingemann H, Grodman C, Cutler E, Duque M, Kadidlo D, Klein AK, et al. Autologous stem cell transplant recipients tolerate haploidentical relateddonor natural killer cell-enriched infusions. Transfusion (2013) 53:412-8. doi:10.1111/j.1537-2995.2012.03764.x

79. Carlens S, Gilljam M, Chambers BJ, Aschan J, Guven H, Ljunggren HG, et al. A new method for in vitro expansion of cytotoxic human CD3-CD56+ natural killer cells. Hum Immunol (2001) 62:1092-8. doi:10.1016/S0198-8859(01) 00313-5

80. Bonanno G, Mariotti A, Procoli A, Folgiero V, Natale D, De Rosa L, et al. Indoleamine 2,3-dioxygenase 1 (IDO1) activity correlates with immune system abnormalities in multiple myeloma. J Transl Med (2012) 10:247. doi:10. 1186/1479-5876-10-247

81. Meehan KR, Talebian L, Tosteson TD, Hill JM, Szczepiorkowski Z, Sentman CL, et al. Adoptive cellular therapy using cells enriched for $\mathrm{NKG} 2 \mathrm{D}+\mathrm{CD} 3+\mathrm{CD} 8+\mathrm{T}$ cells after autologous transplantation for myeloma. Biol Blood Marrow Transplant (2013) 19:129-37. doi:10.1016/j.bbmt.2012.08. 018

82. Frei GM, Persi N, Lador C, Peled A, Cohen YC, Nagler A, et al. Nicotinamide, a form of vitamin B3, promotes expansion of natural killer cells that display increased in vivo survival and cytotoxic activity. ASH Annuual Meeting Abstracts (2011) 118:4035.

83. Lim O, Lee Y, Chung H, Her JH, Kang SM, Jung MY, et al. GMP-compliant, large-scale expanded allogeneic natural killer cells have potent cytolytic activity against cancer cells in vitro and in vivo. PLoS One (2013) 8:e53611. doi:10. 1371/journal.pone.0053611

84. Koehl U, Brehm C, Huenecke S, Zimmermann SY, Kloess S, Bremm M, et al. Clinical grade purification and expansion of NK cell products for an optimized manufacturing protocol. Front Oncol (2013) 3:118. doi:10.3389/ fonc. 2013.00118

85. Meyer-Monard S, Passweg J, Siegler U, Kalberer C, Koehl U, Rovo A, et al. Clinical-grade purification of natural killer cells in haploidentical hematopoietic stem cell transplantation. Transfusion (2009) 49:362-71. doi:10.1111/j. 1537-2995.2008.01969.x

86. Koehl U, Esser R, Zimmermann S, Tonn T, Kotchetkov R, Bartling T, et al. Ex vivo expansion of highly purified NK cells for immunotherapy after haploidentical stem cell transplantation in children. Klin Padiatr (2005) 217:345-50. doi:10.1055/s-2005-872520

87. Lim DP, Jang YY, Kim S, Koh SS, Lee JJ, Kim JS, et al. Effect of exposure to interleukin-21 at various time points on human natural killer cell culture. Cytotherapy (2014) 16:1419-30. doi:10.1016/j.jcyt.2014.04.008

88. Berg M, Lundqvist A, Betters D, Childs RW. In vitro expanded NK cells have increased natural cytotoxity receptors, TRAIL and NKG2D expression, and superior tumor cytotoxicity compared to short-term IL-2-activated NK cells. Blood (2009) 114:463.

89. Peragine N, Torelli GF, Mariglia P, Pauselli S, Vitale A, Guarini A, et al. Immunophenotypic and functional characterization of ex vivo expanded natural killer cells for clinical use in acute lymphoblastic leukemia patients. Cancer Immunol Immunother (2014) 64(2):201-11. doi:10.1007/s00262-014-1614-z

90. Kim EK, Ahn YO, Kim S, Kim TM, Keam B, Heo DS. Ex vivo activation and expansion of natural killer cells from patients with advanced cancer with feeder cells from healthy volunteers. Cytotherapy (2013) 15(231-41):e1. doi:10.1016/ j.jcyt.2012.10.019

91. Pittari G, Liu XR, Selvakumar A, Zhao Z, Merino E, Huse M, et al. NK cell tolerance of self-specific activating receptor KIR2DS1 in individuals with $\operatorname{cog}$ nate HLA-C2 ligand. J Immunol (2013) 190:4650-60. doi:10.4049/jimmunol. 1202120

92. Fujisaki H, Kakuda H, Imai C, Mullighan CG, Campana D. Replicative potential of human natural killer cells. Br J Haematol (2009) 145:606-13. doi:10. $1111 / j .1365-2141.2009 .07667 . x$

93. Lapteva N, Durett AG, Sun J, Rollins LA, Huye LL, Fang J, et al. Largescale ex vivo expansion and characterization of natural killer cells for clinical applications. Cytotherapy (2012) 14:1131-43. doi:10.3109/14653249.2012. 700767

94. Alnabhan R, Madrigal A, Saudemont A. Differential activation of cord blood and peripheral blood natural killer cells by cytokines. Cytotherapy (2015) 17:73-85. doi:10.1016/j.jcyt.2014.08.003

95. Shaim H, Yvon E. Cord blood: a promising source of allogeneic natural killer cells for immunotherapy. Cytotherapy (2015) 17:1-2. doi:10.1016/j.jcyt.2014. 12.001

96. Tomchuck SL, Leung WH, Dallas MH. Enhanced cytotoxic function of natural killer and CD3+CD56+ cells in cord blood after culture. Biol Blood Marrow Transplant (2015) 21:39-49. doi:10.1016/j.bbmt.2014.10.014

97. Cany J, van der Waart AB, Tordoir M, Franssen GM, Hangalapura BN, de Vries J, et al. Natural killer cells generated from cord blood hematopoietic progenitor cells efficiently target bone marrow-residing human leukemia cells in NOD/SCID/IL2R $\gamma$ (null) mice. PLoS One (2013) 8:e64384. doi:10.1371/ journal.pone.0064384

98. Knorr DA, Ni Z, Hermanson D, Hexum MK, Bendzick L, Cooper LJ, et al. Clinical-scale derivation of natural killer cells from human pluripotent stem cells for cancer therapy. Stem Cells Transl Med (2013) 2:274-83. doi:10.5966/ sctm.2012-0084

99. Maus MV, Grupp SA, Porter DL, June CH. Antibody-modified T cells: CARs take the front seat for hematologic malignancies. Blood (2014) 123:2625-35. doi:10.1182/blood-2013-11-492231

100. Shimasaki N, Fujisaki H, Cho D, Masselli M, Lockey T, Eldridge P, et al. A clinically adaptable method to enhance the cytotoxicity of natural killer cells against B-cell malignancies. Cytotherapy (2012) 14:830-40. doi:10.3109/ 14653249.2012.671519

101. Cho FN, Chang TH, Shu CW, Ko MC, Liao SK, Wu KH, et al. Enhanced cytotoxicity of natural killer cells following the acquisition of chimeric antigen receptors through trogocytosis. PLoS One (2014) 9:e109352. doi:10.1371/ journal.pone. 0109352

102. Jiang H, Zhang W, Shang P, Zhang H, Fu W, Ye F, et al. Transfection of chimeric anti-CD138 gene enhances natural killer cell activation and killing of multiple myeloma cells. Mol Oncol (2014) 8:297-310. doi:10.1016/j.molonc. 2013.12.001 
103. Chu J, Deng Y, Benson DM, He S, Hughes T, Zhang J, et al. CS1-specific chimeric antigen receptor (CAR)-engineered natural killer cells enhance in vitro and in vivo antitumor activity against human multiple myeloma. Leukemia (2014) 28:917-27. doi:10.1038/leu.2013.279

104. Imamura M, Shook D, Kamiya T, Shimasaki N, Chai SM, Coustan-Smith E, et al. Autonomous growth and increased cytotoxicity of natural killer cells expressing membrane-bound interleukin-15. Blood (2014) 124:1081-8. doi:10. 1182/blood-2014-02-556837

105. Guven H, Konstantinidis KV, Alici E, Aints A, Abedi-Valugerdi M, Christensson B, et al. Efficient gene transfer into primary human natural killer cells by retroviral transduction. Exp Hematol (2005) 33:1320-8. doi:10.1016/j.exphem. 2005.07.006

106. Glienke W, Esser R, Priesner C, Suerth JD, Schambach A, Wels WS, et al. Advantages and applications of CAR-expressing natural killer cells. Front Pharmacol (2015) 6:21. doi:10.3389/fphar.2015.00021

107. Cheng M, Zhang J, Jiang W, Chen Y, Tian Z. Natural killer cell lines in tumor immunotherapy. Front Med (2012) 6:56-66. doi:10.1007/s11684-012-0177-7

108. Klingemann HG, Wong E, Maki G. A cytotoxic NK-cell line (NK-92) for ex vivo purging of leukemia from blood. Biol Blood Marrow Transplant (1996) 2:68-75.

109. Gong JH, Maki G, Klingemann HG. Characterization of a human cell line (NK92) with phenotypical and functional characteristics of activated natural killer cells. Leukemia (1994) 8:652-8.

110. Yan Y, Steinherz P, Klingemann HG, Dennig D, Childs BH, McGuirk J, et al. Antileukemia activity of a natural killer cell line against human leukemias. Clin Cancer Res (1998) 4:2859-68.

111. Tam YK, Miyagawa B, Ho VC, Klingemann HG. Immunotherapy of malignant melanoma in a SCID mouse model using the highly cytotoxic natural killer cell line NK-92. J Hematother (1999) 8:281-90. doi:10.1089/106161299320316

112. Tam YK, Maki G, Miyagawa B, Hennemann B, Tonn T, Klingemann HG. Characterization of genetically altered, interleukin 2-independent natural killer cell lines suitable for adoptive cellular immunotherapy. Hum Gene Ther (1999) 10:1359-73. doi:10.1089/10430349950018030

113. Hercend T, Meuer S, Reinherz EL, Schlossman SF, Ritz J. Generation of a cloned NK cell line derived from the "null cell" fraction of human peripheral blood. J Immunol (1982) 129:1299-305.

114. Perussia B, Ramoni C, Anegon I, Cuturi MC, Faust J, Trinchieri G. Preferential proliferation of natural killer cells among peripheral blood mononuclear cells cocultured with B lymphoblastoid cell lines. Nat Immun Cell Growth Regul (1987) 6:171-88.

115. Rabinowich H, Sedlmayr P, Herberman RB, Whiteside TL. Increased proliferation, lytic activity, and purity of human natural killer cells cocultured with mitogen-activated feeder cells. Cell Immunol (1991) 135:454-70. doi:10.1016/ 0008-8749(91)90290-R

116. Escudier B, Farace F, Angevin E, Charpentier F, Nitenberg G, Triebel F, et al. Immunotherapy with interleukin-2 (IL2) and lymphokine-activated natural killer cells: improvement of clinical responses in metastatic renal cell carcinoma patients previously treated with IL2. Eur J Cancer (1994) 30A:1078-83. doi:10.1016/0959-8049(94)90460-X

117. Lundqvist A, Abrams SI, Schrump DS, Alvarez G, Suffredini D, Berg M, et al. Bortezomib and depsipeptide sensitize tumors to tumor necrosis factor-related apoptosis-inducing ligand: a novel method to potentiate natural killer cell tumor cytotoxicity. Cancer Res (2006) 66:7317-25. doi:10.1158/0008-5472. CAN-06-0680

118. Lundqvist A, Su S, Rao S, Childs R. Cutting edge: bortezomib-treated tumors sensitized to NK cell apoptosis paradoxically acquire resistance to antigenspecific T cells. J Immunol (2010) 184:1139-42. doi:10.4049/jimmunol. 0902856

119. Imai C, Iwamoto S, Campana D. Genetic modification of primary natural killer cells overcomes inhibitory signals and induces specific killing of leukemic cells. Blood (2005) 106:376-83. doi:10.1182/blood-2004-12-4797

120. Garg TK, Szmania SM, Khan JA, Hoering A, Malbrough PA, Moreno-Bost A, et al. Highly activated and expanded natural killer cells for multiple myeloma immunotherapy. Haematologica (2012) 97:1348-56. doi:10.3324/haematol. 2011.056747

121. Jiang B, Wu X, Li XN, Yang X, Zhou Y, Yan H, et al. Expansion of NK cells by engineered K562 cells co-expressing 4-1BBL and mMICA, combined with soluble IL-21. Cell Immunol (2014) 290:10-20. doi:10.1016/j.cellimm. 2014.04.011
122. Denman CJ, Senyukov VV, Somanchi SS, Phatarpekar PV, Kopp LM, Johnson JL, et al. Membrane-bound IL-21 promotes sustained ex vivo proliferation of human natural killer cells. PLoS One (2012) 7:e30264. doi:10.1371/journal. pone. 0030264

123. Liu Y, Wu HW, Sheard MA, Sposto R, Somanchi SS, Cooper LJ, et al. Growth and activation of natural killer cells ex vivo from children with neuroblastoma for adoptive cell therapy. Clin Cancer Res (2013) 19:2132-43. doi:10.1158/ 1078-0432.CCR-12-1243

124. Betters DM, Smith AL, Berg M, Lundqvist A, Childs RW. In vitro expanded natural killer (NK) cells are more susceptible to Fas-mediated apoptosis compared to fresh and overnight IL-2 activated NK cells. Cancer Res (2010) 70:1271. doi:10.1158/1538-7445.AM10-1271

125. Somanchi SS, Senyukov VV, Denman CJ, Lee DA. Expansion, purification, and functional assessment of human peripheral blood NK cells. J Vis Exp (2011) pii:2540. doi:10.3791/2540

126. Somanchi SS, Somanchi A, Cooper LJ, Lee DA. Engineering lymph node homing of ex vivo-expanded human natural killer cells via trogocytosis of the chemokine receptor CCR7. Blood (2012) 119:5164-72. doi:10.1182/ blood-2011-11-389924

127. Miller JS, Rooney CM, Curtsinger J, McElmurry R, McCullar V, Verneris MR, et al. Expansion and homing of adoptively transferred human natural killer cells in immunodeficient mice varies with product preparation and in vivo cytokine administration: implications for clinical therapy. Biol Blood Marrow Transplant (2014) 20:1252-7. doi:10.1016/j.bbmt.2014.05.004

128. Rosenberg SA, Lotze MT, Muul LM, Leitman S, Chang AE, Ettinghausen $\mathrm{SE}$, et al. Observations on the systemic administration of autologous lymphokine-activated killer cells and recombinant interleukin-2 to patients with metastatic cancer. N Engl J Med (1985) 313:1485-92. doi:10.1056/ NEJM198512053132327

129. Rosenberg SA, Lotze MT, Muul LM, Chang AE, Avis FP, Leitman S, et al. A progress report on the treatment of 157 patients with advanced cancer using lymphokine-activated killer cells and interleukin-2 or high-dose interleukin-2 alone. N Engl J Med (1987) 316:889-97. doi:10.1056/NEJM198704093161501

130. Rosenberg SA, Lotze MT, Yang JC, Topalian SL, Chang AE, Schwartzentruber DJ, et al. Prospective randomized trial of high-dose interleukin-2 alone or in conjunction with lymphokine-activated killer cells for the treatment of patients with advanced cancer. J Natl Cancer Inst (1993) 85:622-32. doi:10.1093/jnci/ 85.8.622

131. Benyunes MC, Higuchi C, York A, Lindgren C, Thompson JA, Buckner CD, et al. Immunotherapy with interleukin 2 with or without lymphokine-activated killer cells after autologous bone marrow transplantation for malignant lymphoma: a feasibility trial. Bone Marrow Transplant (1995) 16:283-8.

132. Lister J, Rybka WB, Donnenberg AD, deMagalhaes-Silverman M, Pincus SM, Bloom EJ, et al. Autologous peripheral blood stem cell transplantation and adoptive immunotherapy with activated natural killer cells in the immediate posttransplant period. Clin Cancer Res (1995) 1:607-14.

133. Caligiuri MA, Murray C, Soiffer RJ, Klumpp TR, Seiden M, Cochran K, et al. Extended continuous infusion low-dose recombinant interleukin-2 in advanced cancer: prolonged immunomodulation without significant toxicity. J Clin Oncol (1991) 9:2110-9.

134. Miller JS, Tessmer-Tuck J, Pierson BA, Weisdorf D, McGlave P, Blazar BR, et al. Low dose subcutaneous interleukin-2 after autologous transplantation generates sustained in vivo natural killer cell activity. Biol Blood Marrow Transplant (1997) 3:34-44.

135. Soiffer RJ, Murray C, Cochran K, Cameron C, Wang E, Schow PW, et al. Clinical and immunologic effects of prolonged infusion of low-dose recombinant interleukin-2 after autologous and T-cell-depleted allogeneic bone marrow transplantation. Blood (1992) 79:517-26.

136. Caligiuri MA, Murray C, Robertson MJ, Wang E, Cochran K, Cameron C, et al. Selective modulation of human natural killer cells in vivo after prolonged infusion of low dose recombinant interleukin 2. J Clin Invest (1993) 91:123-32. doi:10.1172/JCI116161

137. Phillips JH, Takeshita T, Sugamura K, Lanier LL. Activation of natural killer cells via the p75 interleukin 2 receptor. J Exp Med (1989) 170:291-6. doi:10. 1084/jem.170.1.291

138. Burns LJ, Weisdorf DJ, DeFor TE, Vesole DH, Repka TL, Blazar BR, et al. IL2-based immunotherapy after autologous transplantation for lymphoma and breast cancer induces immune activation and cytokine release: a phase I/II trial. Bone Marrow Transplant (2003) 32:177-86. doi:10.1038/sj.bmt.1704086 
139. Bachanova V, Miller JS. NK cells in therapy of cancer. Crit Rev Oncog (2014) 19:133-41. doi:10.1615/CritRevOncog.2014011091

140. Karlhofer FM, Ribaudo RK, Yokoyama WM. MHC class I alloantigen specificity of Ly-49+ IL-2-activated natural killer cells. Nature (1992) 358:66-70. doi:10.1038/358066a0

141. Karre K, Ljunggren HG, Piontek G, Kiessling R. Selective rejection of H-2deficient lymphoma variants suggests alternative immune defence strategy. Nature (1986) 319:675-8. doi:10.1038/319675a0

142. Stroncek DF, Berger C, Cheever MA, Childs RW, Dudley ME, Flynn P, et al. New directions in cellular therapy of cancer: a summary of the summit on cellular therapy for cancer. J Transl Med (2012) 10:48. doi:10.1186/ 1479-5876-10-48

143. Lundqvist A, Berg M, Smith A, Childs RW. Bortezomib treatment to potentiate the anti-tumor immunity of ex-vivo expanded adoptively infused autologous natural killer cells. J Cancer (2011) 2:383-5. doi:10.7150/jca.2.383

144. Rizzieri DA, Storms R, Chen DF, Long G, Yang Y, Nikcevich DA, et al. Natural killer cell-enriched donor lymphocyte infusions from A 3-6/6 HLA matched family member following nonmyeloablative allogeneic stem cell transplantation. Biol Blood Marrow Transplant (2010) 16:1107-14. doi:10.1016/j.bbmt. 2010.02.018

145. Bachanova V, Cooley S, Defor TE, Verneris MR, Zhang B, McKenna DH, et al. Clearance of acute myeloid leukemia by haploidentical natural killer cells is improved using IL-2 diphtheria toxin fusion protein. Blood (2014) 123:3855-63. doi:10.1182/blood-2013-10-532531

146. Frohn C, Hoppner M, Schlenke P, Kirchner H, Koritke P, Luhm J. Antimyeloma activity of natural killer lymphocytes. Br J Haematol (2002) 119:660-4. doi:10.1046/j.1365-2141.2002.03879.x

147. Koehl U, Sorensen J, Esser R, Zimmermann S, Gruttner HP, Tonn T, et al. IL-2 activated NK cell immunotherapy of three children after haploidentical stem cell transplantation. Blood Cells Mol Dis (2004) 33:261-6. doi:10.1016/j.bcmd. 2004.08.013

148. Shah NN, Baird K, Delbrook CP, Fleisher TA, Kohler ME, Rampertaap S, et al. Acute GVHD in patients receiving IL-15/4-1BBL activated NK cells following $\mathrm{T}$ cell depleted stem cell transplantation. Blood (2014) 125(5):784-92. doi:10. 1182/blood-2014-07-592881

149. Lee DA. The off-target effects of nonspecific NK cells. Blood (2015) 125:744-5. doi:10.1182/blood-2014-12-616359

150. Benson DM Jr, Hofmeister CC, Padmanabhan S, Suvannasankha A, Jagannath $\mathrm{S}$, Abonour R, et al. A phase 1 trial of the anti-KIR antibody IPH2101 in patients with relapsed/refractory multiple myeloma. Blood (2012) 120:4324-33. doi:10.1182/blood-2012-06-438028

151. Vey N, Bourhis JH, Boissel N, Bordessoule D, Prebet T, Charbonnier A, et al. A phase 1 trial of the anti-inhibitory KIR mAb IPH2101 for AML in complete remission. Blood (2012) 120:4317-23. doi:10.1182/blood-2012-06-437558

152. Romagne F, Andre P, Spee P, Zahn S, Anfossi N, Gauthier L, et al. Preclinical characterization of 1-7F9, a novel human anti-KIR receptor therapeutic antibody that augments natural killer-mediated killing of tumor cells. Blood (2009) 114:2667-77. doi:10.1182/blood-2009-02-206532

153. Gleason MK, Verneris MR, Todhunter DA, Zhang B, McCullar V, Zhou SX, et al. Bispecific and trispecific killer cell engagers directly activate human NK cells through CD16 signaling and induce cytotoxicity and cytokine production. Mol Cancer Ther (2012) 11:2674-84. doi:10.1158/1535-7163. MCT-12-0692

154. Wiernik A, Foley B, Zhang B, Verneris MR, Warlick E, Gleason MK, et al. Targeting natural killer cells to acute myeloid leukemia in vitro with a CD16 x 33 bispecific killer cell engager and ADAM17 inhibition. Clin Cancer Res (2013) 19:3844-55. doi:10.1158/1078-0432.CCR-13-0505

155. Gleason MK, Ross JA, Warlick ED, Lund TC, Verneris MR, Wiernik A, et al. CD16xCD33 bispecific killer cell engager (BiKE) activates NK cells against primary MDS and MDSC CD33+ targets. Blood (2014) 123:3016-26. doi:10. 1182/blood-2013-10-533398

156. Conlon KC, Lugli E, Welles HC, Rosenberg SA, Fojo AT, Morris JC, et al. Redistribution, hyperproliferation, activation of natural killer cells and CD8 T cells, and cytokine production during first-in-human clinical trial of recombinant human interleukin-15 in patients with cancer. J Clin Oncol (2015) 33:74-82. doi:10.1200/JCO.2014.57.3329

157. Introna M, Borleri G, Conti E, Franceschetti M, Barbui AM, Broady R, et al. Repeated infusions of donor-derived cytokine-induced killer cells in patients relapsing after allogeneic stem cell transplantation: a phase I study. Haematologica (2007) 92:952-9. doi:10.3324/haematol.11132

158. Rettinger E, Kreyenberg H, Merker M, Kuci S, Willasch A, Bug G, et al. Immunomagnetic selection or irradiation eliminates alloreactive cells but also reduces anti-tumor potential of cytokine-induced killer cells: implications for unmanipulated cytokine-induced killer cell infusion. Cytotherapy (2014) 16:835-44. doi:10.1016/j.jcyt.2014.01.003

159. Introna M, Franceschetti M, Ciocca A, Borleri G, Conti E, Golay J, et al. Rapid and massive expansion of cord blood-derived cytokine-induced killer cells: an innovative proposal for the treatment of leukemia relapse after cord blood transplantation. Bone Marrow Transplant (2006) 38:621-7. doi:10.1038/ sj.bmt. 1705503

160. Zhang Z, Zhao X, Zhang T, Wang L, Yang L, Huang L, et al. Phenotypic characterization and anti-tumor effects of cytokine-induced killer cells derived from cord blood. Cytotherapy (2015) 17:86-97. doi:10.1016/j.jcyt. 2014.09.006

161. Durrieu L, Lemieux W, Dieng MM, Fontaine F, Duval M, Le Deist F, et al. Implication of different effector mechanisms by cord blood-derived and peripheral blood-derived cytokine-induced killer cells to kill precursor B acute lymphoblastic leukemia cell lines. Cytotherapy (2014) 16:845-56. doi:10.1016/ j.jcyt.2013.12.010

162. Introna M, Pievani A, Borleri G, Capelli C, Algarotti A, Mico C, et al. Feasibility and safety of adoptive immunotherapy with CIK cells after cord blood transplantation. Biol Blood Marrow Transplant (2010) 16:1603-7. doi:10.1016/ j.bbmt.2010.05.015

163. Lu XC, Yang B, Yu RL, Chi XH, Tuo S, Tuo CW, et al. Clinical study of autologous cytokine-induced killer cells for the treatment of elderly patients with diffuse large B-cell lymphoma. Cell Biochem Biophys (2012) 62:257-65. doi:10.1007/s12013-011-9273-6

164. Schmidt-Wolf IG, Finke S, Trojaneck B, Denkena A, Lefterova P, Schwella $\mathrm{N}$, et al. Phase I clinical study applying autologous immunological effector cells transfected with the interleukin-2 gene in patients with metastatic renal cancer, colorectal cancer and lymphoma. Br J Cancer (1999) 81:1009-16. doi:10.1038/sj.bjc.6690800

165. Yang B, Wang J, Cai LL, Zhu HL, Yu RL, Chi XH, et al. Treatment of multiple solitary plasmacytomas with cytokine-induced killer cells. Cytotherapy (2014) 16:278-84. doi:10.1016/j.jcyt.2013.11.001

166. Olioso P, Giancola R, Di Riti M, Contento A, Accorsi P, Iacone A. Immunotherapy with cytokine induced killer cells in solid and hematopoietic tumours: a pilot clinical trial. Hematol Oncol (2009) 27:130-9. doi:10.1002/ hon. 886

167. Hontscha C, Borck Y, Zhou H, Messmer D, Schmidt-Wolf IG. Clinical trials on CIK cells: first report of the international registry on CIK cells (IRCC). $J$ Cancer Res Clin Oncol (2011) 137:305-10. doi:10.1007/s00432-010-0887-7

168. Schmeel LC, Schmeel FC, Coch C, Schmidt-Wolf IG. Cytokine-induced killer (CIK) cells in cancer immunotherapy: report of the international registry on CIK cells (IRCC). J Cancer Res Clin Oncol (2014) 141(5):839-49. doi:10.1007/ s00432-014-1864-3

169. Li XD, Xu B, Wu J, Ji M, Xu BH, Jiang JT, et al. Review of Chinese clinical trials on CIK cell treatment for malignancies. Clin Transl Oncol (2012) 14:102-8. doi:10.1007/s12094-012-0768-4

170. Linn YC, Niam M, Chu S, Choong A, Yong HX, Heng KK, et al. The anti-tumour activity of allogeneic cytokine-induced killer cells in patients who relapse after allogeneic transplant for haematological malignancies. Bone Marrow Transplant (2012) 47:957-66. doi:10.1038/bmt.2011.202

171. Rutella S, Iudicone P, Bonanno G, Fioravanti D, Procoli A, Lavorino C, et al. Adoptive immunotherapy with cytokine-induced killer cells generated with a new good manufacturing practice-grade protocol. Cytotherapy (2012) 14:841-50. doi:10.3109/14653249.2012.681038

172. Mackall CL, Merchant MS, Fry TJ. Immune-based therapies for childhood cancer. Nat Rev Clin Oncol (2014) 11:693-703. doi:10.1038/nrclinonc.2014. 177

173. Miller JS, Oelkers S, Verfaillie C, McGlave P. Role of monocytes in the expansion of human activated natural killer cells. Blood (1992) 80:2221-9.

174. Bertaina A, Merli P, Rutella S, Pagliara D, Bernardo ME, Masetti R, et al. HLA-haploidentical stem cell transplantation after removal of $\alpha \beta+T$ and B cells in children with nonmalignant disorders. Blood (2014) 124:822-6. doi:10.1182/blood-2014-03-563817 
175. Rutella S, Locatelli F. Is there a role for cytokine-induced killer cells in cancer immunotherapy? Immunotherapy (2012) 4:867-9. doi:10.2217/imt.12.89

Conflict of Interest Statement: The authors declare that the research was conducted in the absence of any commercial or financial relationships that could be construed as a potential conflict of interest.
Copyright $\odot 2015$ Pittari, Filippini, Gentilcore, Grivel and Rutella. This is an openaccess article distributed under the terms of the Creative Commons Attribution License (CC BY). The use, distribution or reproduction in other forums is permitted, provided the original author(s) or licensor are credited and that the original publication in this journal is cited, in accordance with accepted academic practice. No use, distribution or reproduction is permitted which does not comply with these terms. 